Research Article

Anja Mansrud*, Inger Marie Berg-Hansen

\title{
Animist Ontologies in the Third Millennium BCE? Hunter-Gatherer Persistency and Human-Animal Relations in Southern Norway: The Alveberget Case
}

https://doi.org/10.1515/opar-2020-0176

received November 19, 2020; accepted June 18, 2021

Abstract: This article aims to contribute novel data and perspectives into the long-standing debate about economic strategies in the fourth and third millennium in South Norway, by introducing novel results from a Pitted Ware coastal site in Agder County, southern Norway. The analysis of artifactual and faunal assemblages as well as lipid analysis from ceramics indicate a varied subsistence economy with terrestrial hunting, gathering, and specialized marine fishing strategies, targeting Atlantic bluefin tuna and seals. These procurement strategies were maintained throughout the middle and into the late Neolithic period (c. 3300-2200 BCE). No unequivocal evidence of cultivation was documented before the early Bronze Age, around $1700 \mathrm{BCE}$. This article maintains that exploring and explaining long-time continuity, and the environmental, cultural, and social mechanisms, which underwrite enduring traditions, remains a pertinent issue in Neolithic archeology. To broaden our understanding of the causes underlying cultural persistence, we need to move beyond a view of foraging peoples as either ecologically adapted or as economically optimized and employ a perspective that acknowledges the fundamental importance of human-animal relations in prehistoric lives and worldviews. Drawing on insights from relational anthropology and multispecies archaeology, we maintain that an animist ontology endured among the Pitted Ware groups and endorsed the foraging persistency characterizing the third millennium in Southern Norway.

Keywords: animism, fishing, Middle Neolithic, neolithization, Norway

\section{Introduction}

Until the end of the Neolithic (c. 3900-2400 BCE), South Norway ${ }^{1}$ has been described as a cultural patchwork in which several archeologically defined cultures or techno-complexes co-existed: the Pitted Ware or

Special Issue: THE EARLY NEOLITHIC OF EUROPE, edited by F. Borrell, I. Clemente, M. Cubas, J. J. Ibáñez, N. Mazzucco, A. Nieto-Espinet, M. Portillo, S. Valenzuela-Lamas, \& X. Terradas

1 South Norway refers to the whole of Norway south of Nordland. South-eastern Norway encompasses the counties of Viken, Oslo, Telemark \& Vestfold, and southern Norway encompass the county of Agder.

\footnotetext{
* Corresponding author: Anja Mansrud, Fornminneavdelingen, Arkeologisk museum/Jernaldergården, University of Stavanger, Stavanger 4036, Norway, e-mail: anja.mansrud@uis.no

Inger Marie Berg-Hansen: Department of Archaeology, Museum of Cultural History, University of Oslo, Pb 6762 St. Olavs plass, 0130 Oslo, Norway, e-mail: i.m.berg-hansen@khm.uio.no

ORCID: Anja Mansrud 0000-0002-8660-9137; Inger Marie Berg-Hansen 0000-0001-6900-0330
} 
Cord Stamp Culture (PWC/CSC, 3300-2800 BCE), the Funnel Beaker Culture (FBC, 3900-2800), the Battle Axe Culture (BAC, 2800-2400), and the Bell Beaker culture (BBC, 2500-2300 BCE). The question of economic strategies among these groups - foraging or farming - has been much debated. In South Norway, palynological and faunal data give sparse indications of husbandry and cereal cultivation in the fourth and third millennia BCE. Most coastal sites show evidence of a sustained foraging economy, with an emphasis on the utilization of marine resources, and numerous Neolithic sites in the interior and mountain areas are associated with fishing and hunting of large ungulates (Bergsvik, 2012; Glørstad, Solheim, \& Persson, 2020; Hjelle, Hufthammer, \& Bergsvik, 2006; Indrelid, 1994; Mjærum, 2018; Prescott, 2020; Solheim, 2012). This has led researchers to question whether there ever existed a full-scale Neolithic subsistence economy in Norway, defining elements being farming and cultivation, stockholding, and dwelling in dual-aisled longhouses (Prescott, 1996, 2020). Much effort has been put into detecting the first evidence of cultivation or domesticates and pondering over why agriculture never gained a long-lasting foothold, implicitly assuming a link between pottery, husbandry, and cultivation, as well as the superiority of this economic strategy over hunting and gathering (Prescott, 2020).

Discussions concerning the fourth and third millennia BCE development in South Norway comprises several alternative scenarios for the development, more or less assuming a gradual development and transformation, e.g. through assimilation, of the Mesolithic society toward a fully developed Neolithic society c. 2400 BCE. Suggestions include, on the one hand, a development with a succeeding replacement of societies with either farming or foraging as economic basis, and on the other hand, a continuation of groups with a foraging adaptation existing parallel with early farming groups, and a re-introduction of farming in the middle of the third millennium (e.g., Brøgger, 1925; Bakka, 1973; Bergsvik 2012; Bergsvik, Hjelle, Halvorsen, Olsen, \& Zinsli, 2020; Glørstad, 2002, 2009; Glørstad \& Solheim, 2015; Glørstad et al., 2020; Hallgren, 2008; Hinsch, 1955, 1956; Hjelle et al., 2006; Mikkelsen, 1989; Nielsen, Persson, \& Solheim, 2019; Olsen, 1992, 2013; Østmo, 1988; Prescott, 1996, 2020; Persson, 1998; Prescott \& Glørstad, 2012; Reitan, Sundström, \& Stokke, 2018; Solheim, 2012).

This article aims to contribute fresh data and perspectives to this long-standing debate. Resolving the question of subsistence strategies has been hampered by the lack of direct evidence such as animal bones and cereals. In 2018, an excavation undertaken at the island of Tromøya in Agder County, Southern Norway (Figure 1), revealed a large assemblage of pottery, lithics, and faunal remains in a well-preserved cultural layer, protected under colluvial deposits. Most dates fall within the later part of the Middle Neolithic period (Mansrud, Stokke, Viken, \& Berg-Hansen, in press). The faunal remains and the preliminary scientific analysis present a renewed opportunity for investigating Middle Neolithic subsistence strategies. Recently, scholars have proposed that hunter-fisher-gatherers in South Norway continued their traditional way of life and resisted the economic transition to agriculture and stock-raising, while partaking in interregional coastal networks of exchange and contact (Bergsvik, 2012; Bergsvik et al., 2020; Glørstad, 2009, 2010, p. 265; Glørstad et al., 2020). Despite people's knowledge of, and documented interaction with, groups living otherwise foraging traditions were sustained. Exploring and explaining this long-time continuity, and the environmental, cultural, and social mechanisms that underwrite enduring traditions, remains a pertinent issue. The debates about economic adaptations and strategies remain anchored in an anthropocentric metanarrative, centered on human exploitation of animals and their products, as objects for consumption, exchange, and trade. In this article, we aim to explore the role of human-animal relationships in foraging persistency.

To broaden our understanding of the causes underlying this persistence, we need to move beyond a view of foraging peoples as either ecologically adapted or as economically optimized and employ a perspective that acknowledges the fundamental importance of human-animal relations in prehistoric lives and worldviews. Foraging is based on a complex system of knowledge and requires precise ecological knowledge of weather, topography, and plant and animal resources (e.g. Binford, 2001; Kelly, 2013 [1995]). However, living with animals is also a constant in any human society (Oma \& Goldhahn, 2020, p. 12). A multi-species archeology offers an analytical perspective suited for addressing this issue. Birch (2018a, p. 4) defines multispecies archeology as archeo-ecology: "an archaeology of life which understands the past through networks and interactions rather than stochastic events and places.” Taking the local palaeoenvironment, faunal remains and ecofacts as a starting point, a multispecies perspective sees other species as fundamentally integral to prehistoric life and considers the environment as co-habited by humans and other species (O'Connor, 2018). Foraging in this perspective entails an intimate familiarity 

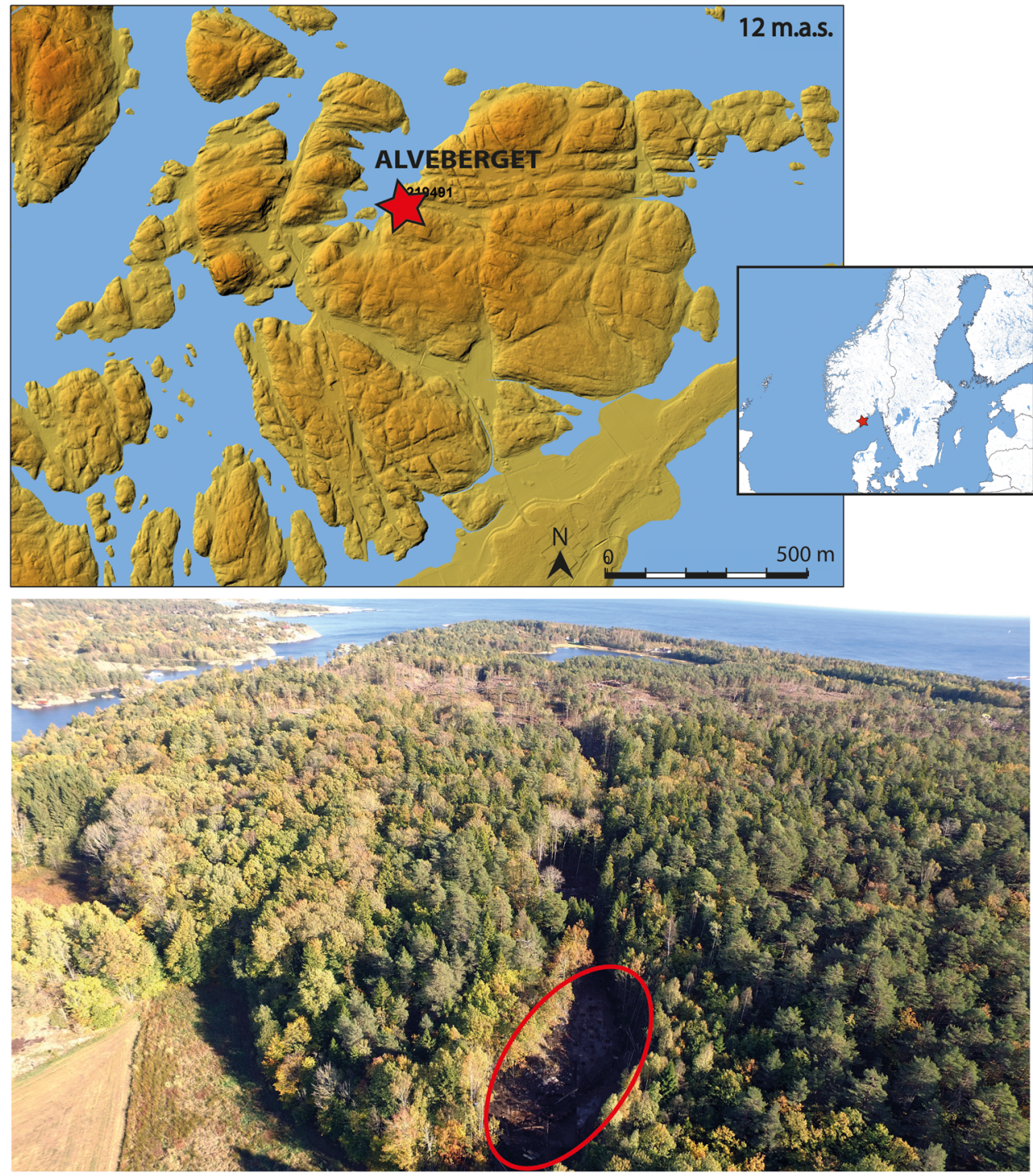

Figure 1: Alveberget is located on the eastern Skagerrak coast in Arendal, Agder County (upper, right). In the Middle Neolithic, when the sea-level was about 12 meters higher than at present, the area was an archiplago with eminent potential for in-shore and out-shore fishing. The site was situated on a small island, sloping down towards a sheltered bay (Illustration: J. S. F. Stokke/S. Kristensen/I. M. Berg-Hansen @ 2020 Museum of Cultural History, University of Oslo).

with the rhythms of local and individual animals - where they move at different times of the day, where they drink, eat and rest (Birch, 2018b; Grøn, 2012; Overton, 2018). The seascape can be similarly regarded as specific task-scape, which necessitates intimate knowledge of tides, currents and movement of fish, as well as specialized fishing equipment (Van de Noort, 2011, pp. 72-73). By focusing on how practical experiences and encounters with animals contributed to shape human perception of them, these perspectives permit novel lines of inquiry into the ontological status of animals in prehistory (Birch, 2018b; Hill, 2013; Oma, 2018; Overton \& Hamilakis, 2013). Coupled with understandings advanced within the ontological turn, this approach enables a shift in perspective that acknowledges how prehistoric communities were entwined with nonhumans in social as well as ecological and economic ways. In the following, the main results highlighting the subsistence activities at Alveberget will be presented and discussed. We then proceed to evaluate the results in a multispecies perspective and contextualize our case in the wider regional context of the PWC. Drawing on insights from relational anthropology, we consider foraging practices as deeply rooted in underlying, intangible beliefs and worldviews (Descola, 2010, 2014), and propose that an animist ontology endorsed the Middle Neolithic foraging traditions. 


\section{Alveberget - A Middle Neolithic Coastal Site}

The Alveberget site was located on a small island, on a sloping terrace close to the shore. From about 3000 BCE, a shallow bay with a northern outlet toward the open Skagerrak Sea was located just below the site (Figure 1). Artifacts were found in sandy deposits across the site; however, a culture layer at the lower part of the slope comprised a unique assemblage of well-preserved faunal remains, pottery, and lithic artifacts (Figures 2-5). Various events associated with settlement activities and specialized workshop activities were deduced from the finds and their distribution (Mansrud et al., in press).

Results from soil micromorphology and pollen analyses show that the sandy deposits covering the cultural layer represent colluvial soil redeposited from the upper part of the terrace. These erosion incidents were related to episodes of forest clearance and cultivation in the Bronze Age and Iron Age. Several episodes of activity were identified in the sandy layers, separated by phases of humus build-up (Macphail, 2019). The cultural layer was affected by tree root disturbance, resulting in slightly mixed dates (Figure 3). A total of 31 C14-dates indicate activity in four phases from c. 3300 BCE to c. $1000 \mathrm{CE}^{2}$. Seventeen dates fall within the timeframe 3300-2200 BCE (Figure 4). The dated materials comprise charcoal from the cultural layer and food crusts from pottery. Radiocarbon dates from food crusts, which might have contained marine organisms, represent a potential source of error because of the marine reservoir effect. This can be mitigated by measuring the content of $\mathrm{C} 13$ (Craig et al., 2007). The C13 values from Alveberget food crusts lay between -24.1 and -25.6 , indicating predominantly terrestrial content in the dated sherds (Lundholm \& Ekman, 2020). Six sherds were dated to 2800-2200 BCE, with an overlap around 2700 BCE. The result is in accordance with the dates from charcoal. All the Neolithic dates were distributed in wide plateaus (Figure 4a and b), but the results were consistent and agree well with the artifacts as well as with the local shoreline displacement curve (Romundset, 2018).

Following the general South-Scandinavian chronology, with a division into the Early Neolithic (c. 3900-3300 BCE), Middle Neolithic A (3300-2800 BCE), Middle Neolithic B (2800-2400 BCE), and Late Neolithic (2400-1700 BCE), this places the main activity phase in the latter part of the Middle Neolithic (Mischka, Furholt, Hinz, Noble, \& Olausson, 2014). The composition of the assemblage, including cylindrical core technology, and flint and slate tanged points, is associated with the $\mathrm{PWC}^{3}$ (3600-2200 BCE), a coastal phenomenon in Denmark and Sweden, named after the simple, pit-ornamented pottery (Iversen, 2010).

\subsection{The Archaeological Material from Alveberget}

The pottery comprises c. 15,000 sherds (c. $55 \mathrm{~kg}$ ) making it the second largest assemblage of Neolithic pottery in southern Norway (cf. Østmo, 2008). The pottery is coarse-grained and tempered with quarts, feldspar, and bone. Approximately 3,000 sherds were decorated with cord stamps, pits, and various other imprints, carefully shaped into beautiful geometric and linear patterns (Figure 5). The cord stamp decoration links the material to a pottery tradition with long continuity in South Norway, initially appearing in the Early Neolithic Funnel Beaker horizon and continuing throughout the Neolithic (Glørstad, 2009; Nielsen et al., 2019; Østmo, 2008, 2010; Skjølsvold, 1977). Many sherds with visible charred food crusts, indicate heating of food in the vessels. Potsherds in different stages of burning and layers of crushed feldspar and quartzite, probably collected to be used as temper, suggest that pottery was also produced on-site. Thirtythree pointed bases, mainly distributed in the bottom layers at the north-eastern part of the site, imply that at least 33 vessels of various sizes had been in use (Figure 5).

2 See supplementary table at https://doi.org/10.1515/opar-2020-0176.

3 In South Norway, the term Cord Stamp culture has been suggested for this complex, as the cord stamp is a more characteristic decorative element on the vessels in this region (Bergsvik et al., 2020; Østmo, 2010). 

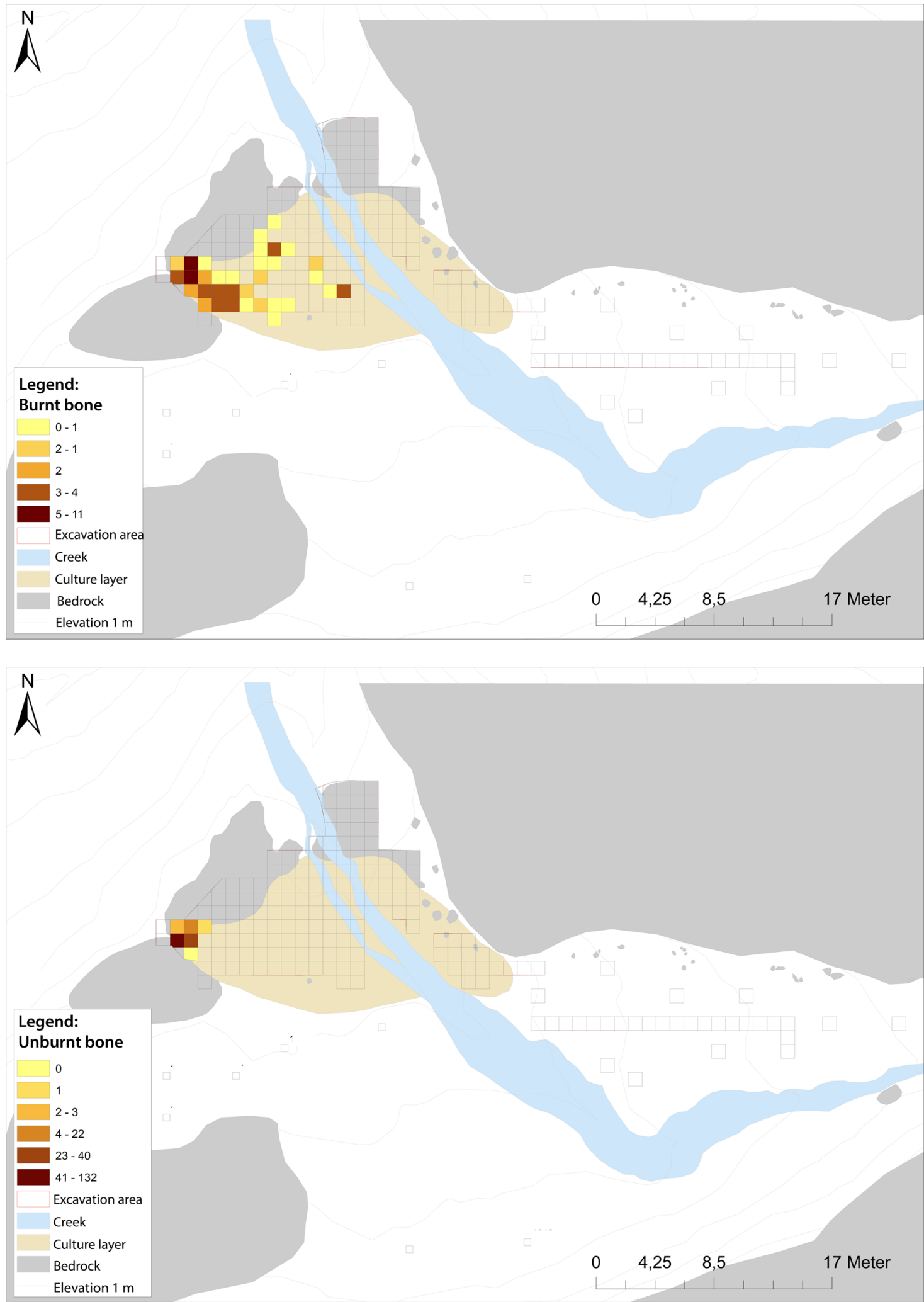

Figure 2: Distribution of cultural layer and animal bones at the Alveberget site. The unburnt bones (lower) were found in small rock hollows along the western edge of the site, close to the past shoreline, suggesting that faunal remains had been discarded in the sea. The burnt bones (upper) were more widely distributed (Map: J. S. F. Stokke/I. M. Berg-Hansen $\subset 2020$ Museum of Cultural History, University of Oslo). 


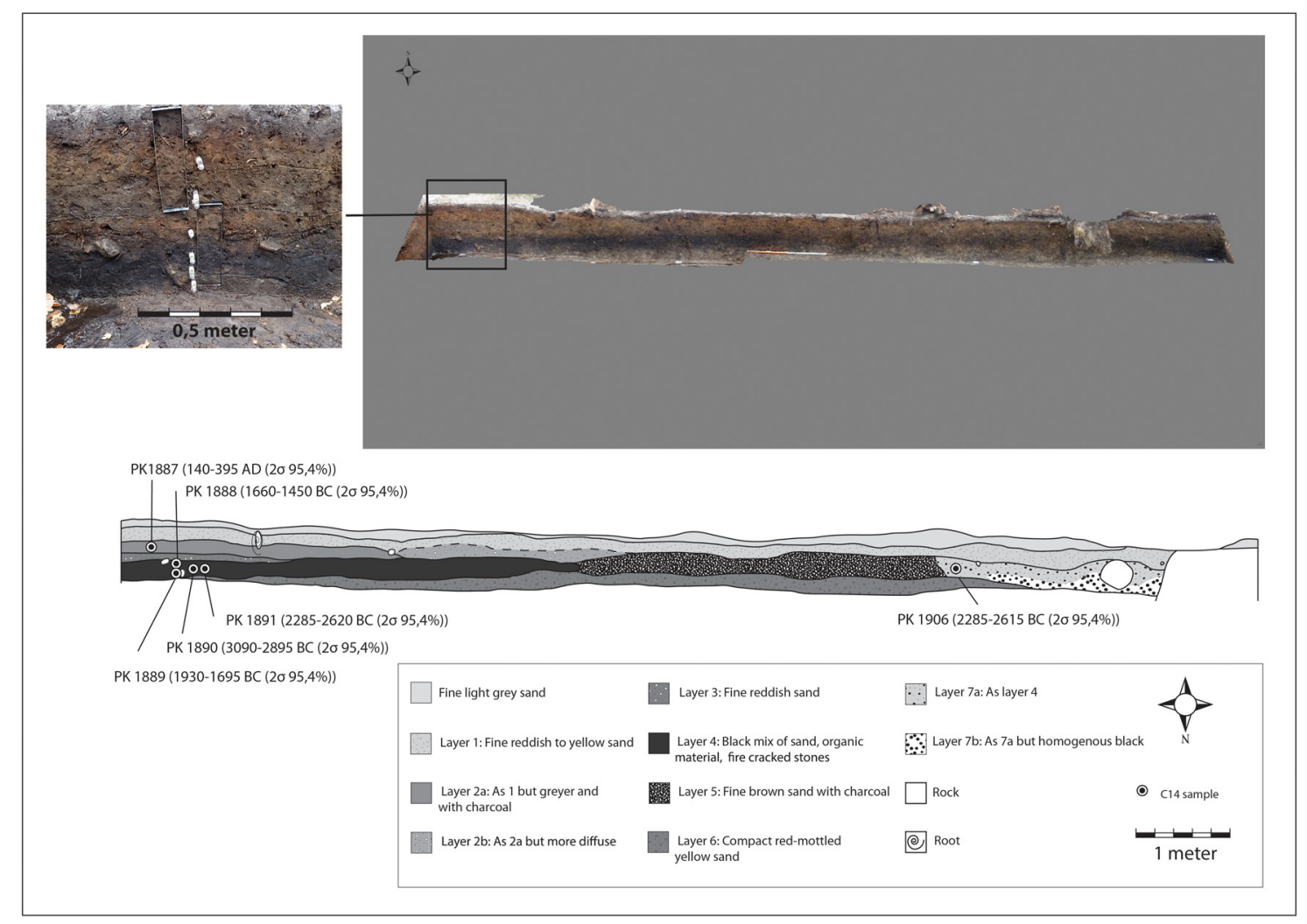

Figure 3: Stratigraphy of one of the sections, C1600, with C14-samples marked. The box to the left show micromorphology and pollen outtakes during sampling. Layers 4, 7a and $7 \mathrm{~b}$ represent layers deposited during the Middle Neolithic, partly disturbed by bioturbation. Layers 1, 2a-b, and 3 are colluvial layers, indicating slope erosion, presumably due to removal of vegetation cover. Charcoal from layer 2a was dated to the Roman Iron Age (illustration and photos: A. Mansrud/J. S. F. Stokke/M. Svendsen (c) 2020 Museum of Cultural History, University of Oslo).

The lithic assemblage comprises c. 56,800 artifacts (tools and debitage), of which 96\% are made of flint. Regionally procured beach flint constitute the main flint raw material, while several flakes from polished flint axes indicate that axes imported from southern Scandinavia were also utilized for blade and tool production. The lithic assemblage attests to the importance of hunting - in all, 373 arrowheads of various sizes were classified - making up about $1 \%$ of the lithic assemblage. The flint blank production was focused on making blades from cylindrical cores by indirect percussion. The blade blanks were mostly worked into tanged points, typologically defined as Beckers type A-D (Becker, 1951) (Figure 6). Scrapers and various informal flint tools were also produced and utilized at the site. Fifty-three points made from ground slate and debitage from the production of slate points were retrieved. Slate points are more common in the interior lowland and mountains of Norway as well as along the western coast (Nærøy, 1993; Olsen, 1992; Østmo, 2008; Solheim, 2012). The only tools made from organic materials are fragments of two fishhooks (Figure 7). Both are burnt and fragmented, comprising only the arch of the hook. The absence of tip and shaft makes it impossible to typify the hooks, but characteristic PWC fishhooks have barbs and an extended knob for fastening the line (Hernek, Jonsson, \& Streiffert, 2004; Skjølsvold, 1977; Wammer, Mansrud, Nymoen, \& Kvalø, 2019).

\subsection{Traces of Subsistence at Alveberget}

A small assemblage of burnt and unburnt animal bones was uncovered. The burnt bones were distributed throughout the cultural layer, whereas the unburnt bones occurred in small rock hollows along the edge of the lower terrace, close to the shoreline. This suggests that organic waste had been discarded in the sea and 


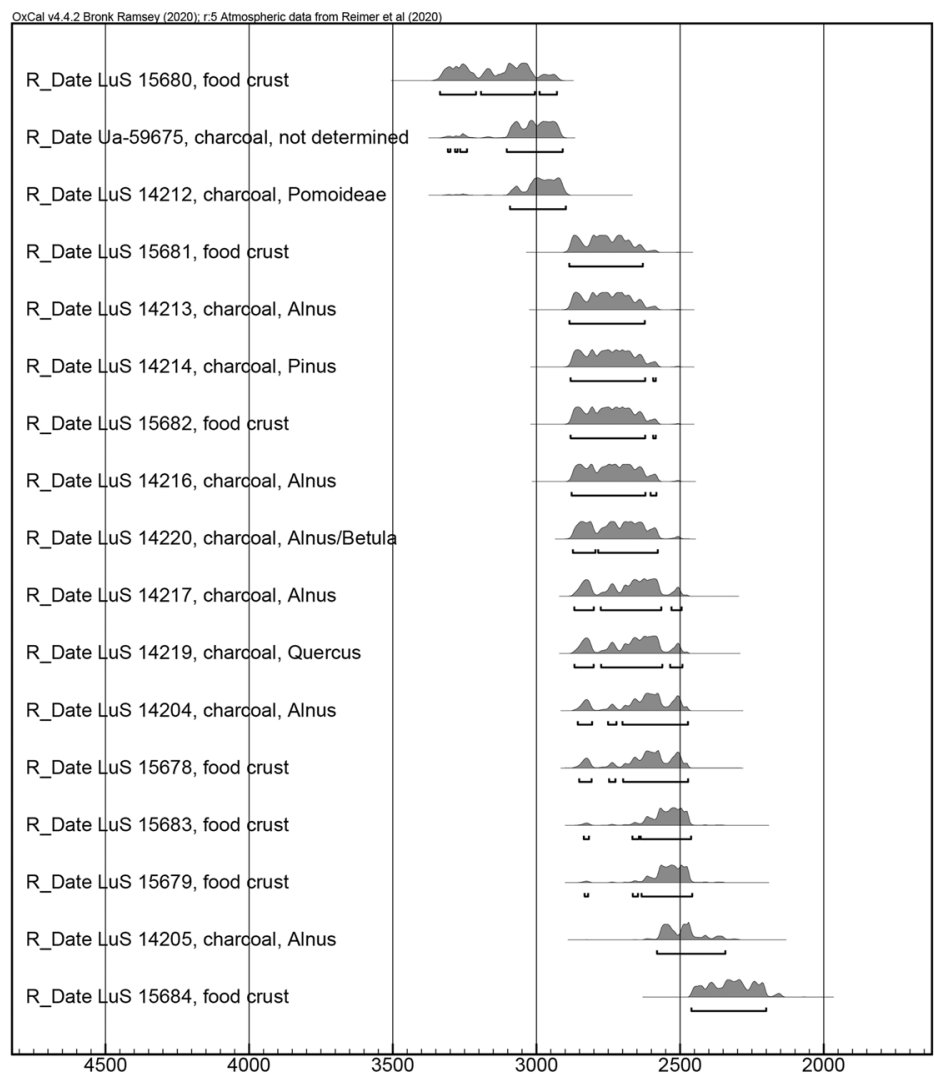

(a)

Calibrated date (calBC)

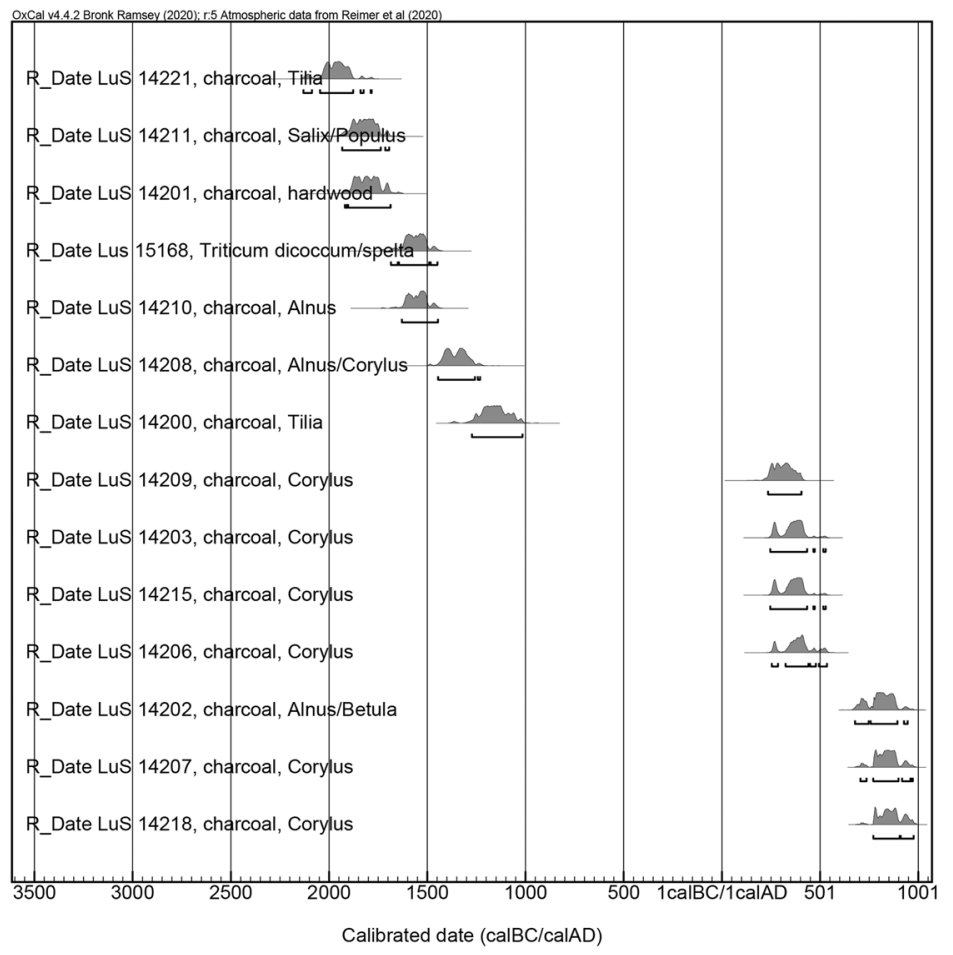

Figure 4: ( $a$ and $b$ ) Radiocarbon dates from the Alveberget site. From a total of 31 C14 dates, 17 falls within the period 3350-2200 cal. BCE. The remaining dates are linked to forest activity in the Bronze Age and Iron Age. LuS, analyzed at the Radiocarbon Dating Laboratory, Department of Geology, Lund University (Nielsen \& Rundgren, 2019a, 2019b, 2020). Ua, analyzed at Ångströmlaboratoriet, Uppsala University (Possnert \& Balkefors (2018). Calibrations performed using 0xCal v4.4.2 Bronk Ramsey (2020); r:5, atmospheric data from Reimer et al. (2020). 


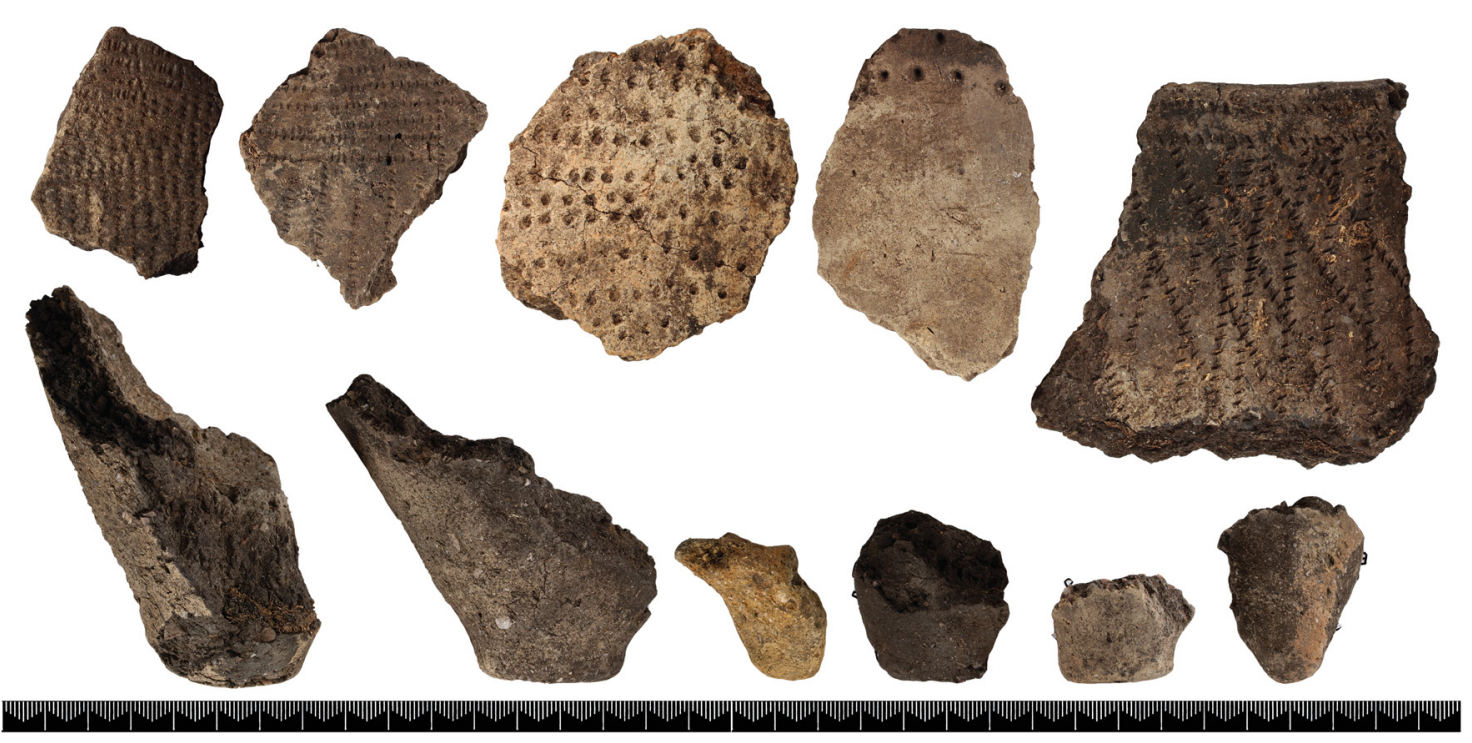

Figure 5: Sherds of coarse-grained pottery from the Alveberget site (C61487). Upper row: sherds with different types of decoration: thread, cord stamps, pits, and cord stamps in geometric lines. Lower row: selection of pointed bases, different sizes. Scale: millimeters. Photo: I. M. Berg-Hansen, (C) 2020 Museum of Cultural History, University of Oslo.

got trapped and preserved in these pockets (Figure 2). The faunal composition was diverse, comprising terrestrial and marine mammals, birds, and fish (Prata \& Sjöling, 2019) (Figure 7; Table 1). The burnt assemblage included fragments of skulls and extremities from seals, including parts of an ear bone (pars petrosa and bulla tympanica) presumably from harp seal (Pagophilus groenlandica) (Prata \& Sjöling, 2019). The harp seal is an arctic species not previously identified in Neolithic sub-fossil bone assemblages in south-eastern Norway (Hufthammer, 1997, 2006), but the species frequently occurs in Pitted Ware middens on the Swedish West Coast and in Denmark during the sub-Atlantic chronozone, when the climate and sea temperatures were different than today (Bennike, Rasmussen, \& Aaris-Sørensen, 2008; Jonsson, 2007, p. 244; Nielsen \& Persson, 2020, pp. 10-20). Terrestrial mammals included a talus bone from a fox and various teeth and extremity fragments identified as dog or fox. Except for the dog bones, no evidence of domestic animals was identified. Two fragments of deer antlers, possibly representing a tool, as well as vertebrae and tubular fragments of unidentified birds and fish were also recorded. The collection of unburnt bones included a tail fragment of seal and jaw and vertebrae fragments of cod (Gadus morhua), but the majority were vertebrae and skull fragments of Atlantic Bluefin Tuna (Thunnus thynnus) (Prata \& Sjöling, 2019) (Figure 7; Table 1).

One macrofossil sample contained two charred grains, identified as emmer or spelt wheat (Triticum dicoccum/spelta) One of these were C14, dated to the early Bronze Age (1685-1450 BCE, LuS 15168) (Östman, Hristova, Eriksson, Hristov, \& Wallin, 2019). The preliminary results thus support the argument advanced by Prescott $(1996,2020)$ that full-scale farming did not commence until the Late Neolithic/Early Bronze Age, whereas multiple lines of evidence suggest that foraging and fishing remained fundamental in the subsistence strategy throughout the Middle Neolithic period at the site.

\section{Mobility and Seasonality in a Multi-Species Perspective}

Situated on an island, the activities at Alveberget most likely represent seasonal habitation. The large quantity of pottery, used for cooking and possibly also for storage, may suggest continuous reuse of the same site, aimed at specific, seasonal activities and potentially involving larger gatherings of people on the island. The site location and the palaeoecological setting, with water levels c. 12 higher than the present, 


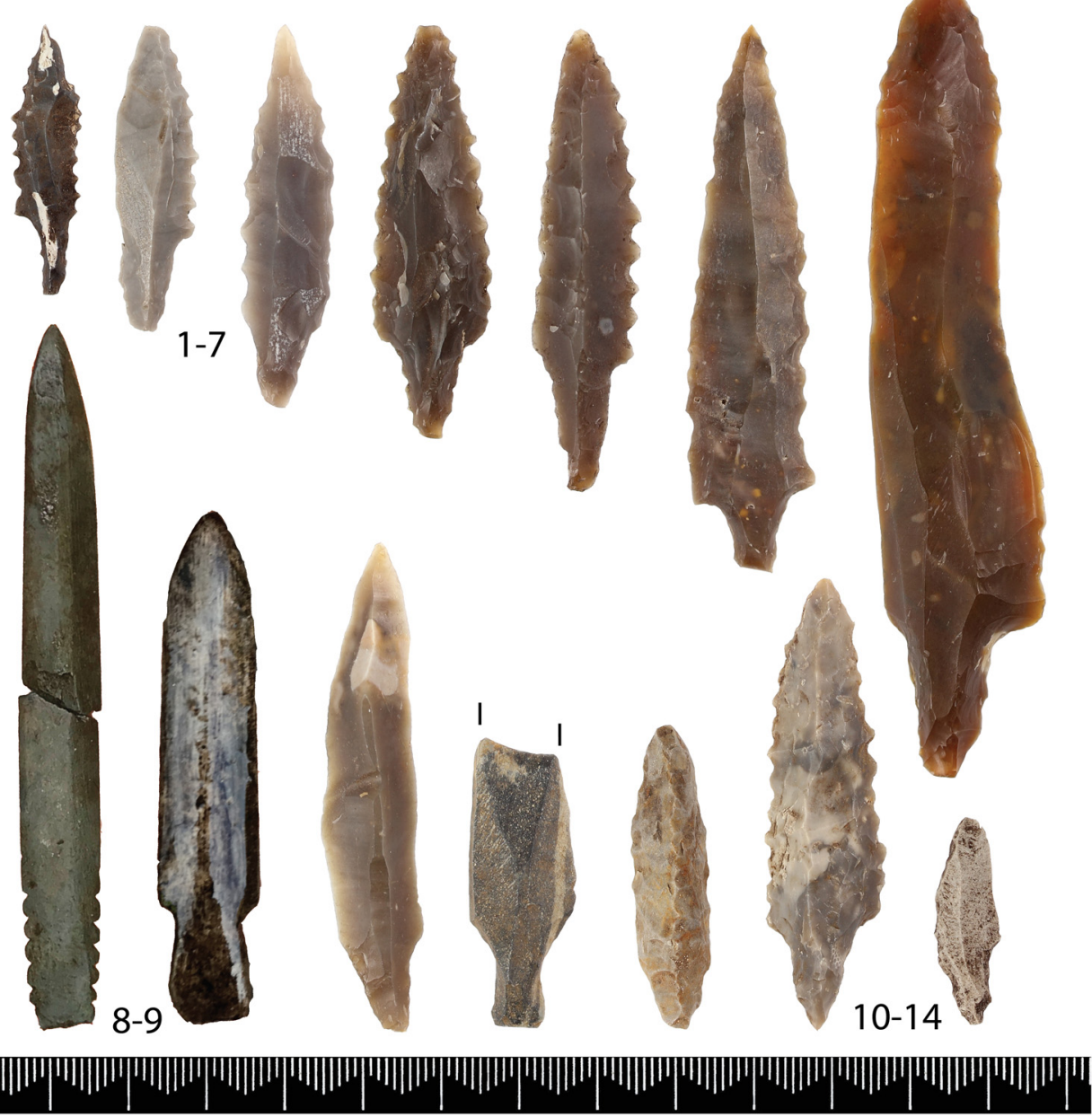

Figure 6: Selection of characteristic projectile points made from flint (1-5, 10,12-14), rhyolite (11) and slate (8 and 9) (C61487). No. 3 and 5 have polished surfaces showing that they were made from polished flint axes. Scale: millimeters. Illustration: I. M. Berg-Hansen, () 2020 Museum of Cultural History, University of Oslo.

would have provided excellent conditions for fishing and marine hunting. As noted, the spatial distribution of the unburnt faunal assemblage indicates that fish was processed and discarded in the bay outside the site. This activity would have attracted sea birds and potentially also fishes like cod, saithe, whiting, and haddock, which feed close to the shore. The small fishhooks were probably used for fishing cod, which was identified in the faunal assemblage. A well-known fishing technique from the area was to entice the fish by attaching a small net filled with chopped mussels to the line. The line would regularly be pulled up, so the waste was spilled into the sea. The feeding fish were then easily caught on a hook (Dannevig \& van der Eynden, 1986, pp. 45-47).

According to historical accounts, shoals of large tuna used to migrate into the north-eastern Skagerrak coast in the summer. They were caught on hooks or harpooned from boat (Dannevig \& van der Eynden, 1986, pp. 205-280). The Alveberget bay, with its outlet towards the open Skagerrak Sea, had an ideal location for monitoring tuna shoals and seals seasonally preying on smaller species like mackerel (Scomber scombrus), herring (Clupea harengus), and sprat (Sprattus sprattus). The herring is an ecological key species in these habitats, providing nutrition for predating cod, tuna, seabirds, seals, and whales (Dannevig \& van der Eynden, 1986, pp. 90-196), but the importance of this species in prehistory is difficult to determine as herringbone is especially exposed to taphonomic loss (cf. Hufthammer, 1992, pp. 17-19; Jonsson, 1995). Small fish bones were noted in the assemblage but could not be determined by species. Remarkably, some 

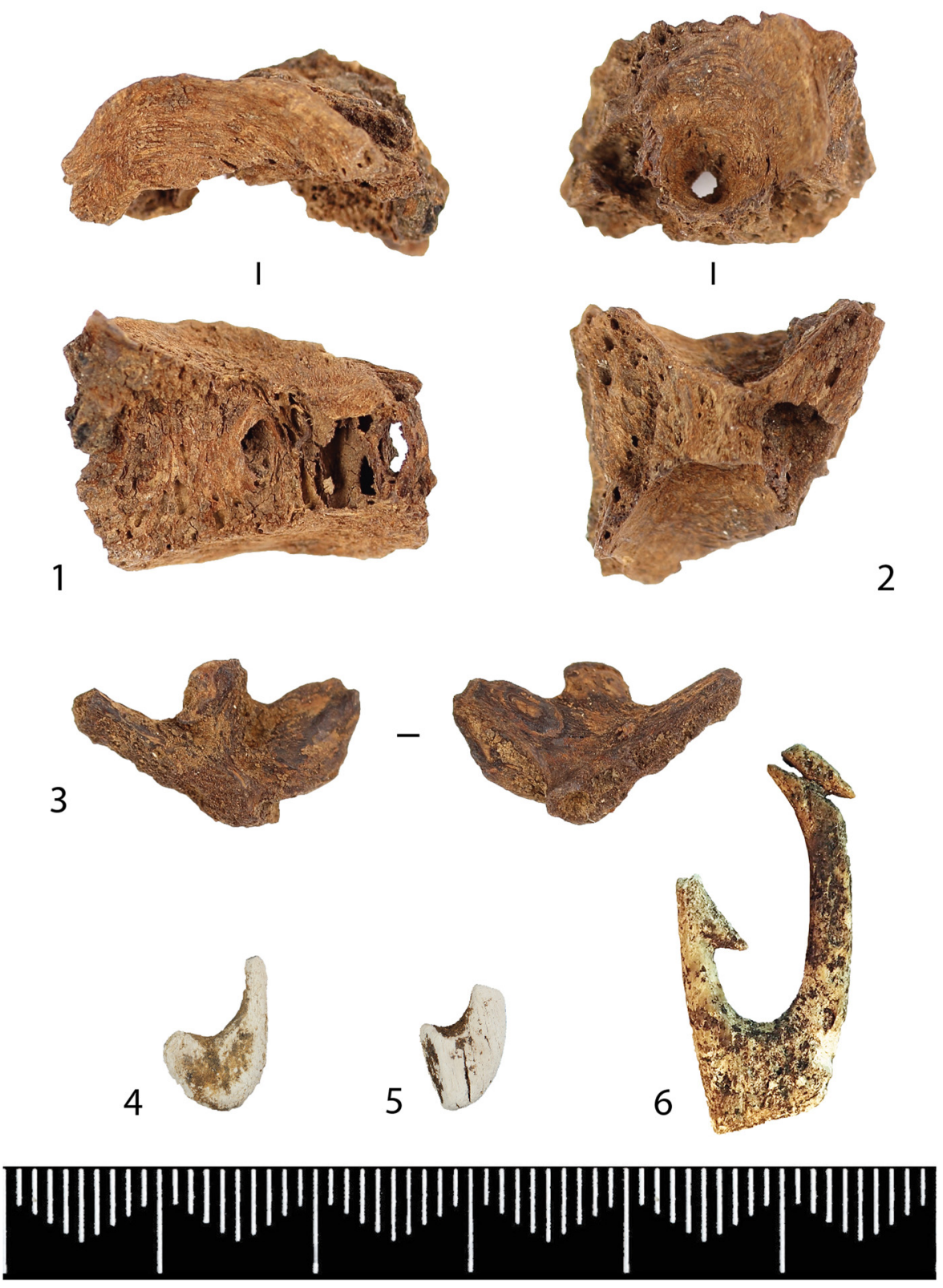

Figure 7: A small collection of unburnt fish bones was preserved at Alveberget (C61487), e.g., vertebrae from fish (1-2) and premaxillare from Cod (Gadus morhua) (3). Fragments of two burnt, small fishhooks (4-5) made from bone or antler were also found. These are likely of similar type as fishhooks found at the contemporary site Rörvik, West-Sweden (6). Scale: millimeters. Photo: I. M. Berg-Hansen and E. U. Wammer, Illustration: I. M. Berg-Hansen @ 2020 Museum of Cultural History, University of Oslo.

of the tuna vertebrae from Alveberget belonged to large specimen, probably measuring $1.5 \mathrm{~m}$ and weighing about 70 kilos. Cut marks observed on a vertebra show that large tuna were also gutted at the site (Prata \& Sjöling, 2019). Toggle harpoons and a large fishhook associated with an assemblage of bones of tuna and orca, dated to the 3700-2500 BCE, have been found at Jortveit, a wetland site $40 \mathrm{~km}$ south of Alveberget (Nielsen \& Persson, 2020). This shows that the PWC groups possessed varied and specialized fishing equipment and had the knowledge required for targeting large marine species.

While the marine resources seem to have been of major importance, the extensive production of arrowheads and C13-values from pottery additionally demonstrate the importance of terrestrial hunting. Ungulates are represented by fragments of roe deer and deer antler, presumably used as tools or raw material for tools such as fishing equipment, punches, and axes, which have been found at other PWC sites (Hernek et al., 2004; 
Table 1: Burnt and unburnt animal bones from the Alveberget site. Osteological analysis performed by Prata and Sjöling (2019)

\begin{tabular}{|c|c|c|}
\hline Unburnt bone & NISP & Weight \\
\hline Dog (Canis familiaris) & 1 & 0.6 \\
\hline Fox/dog (Vulpes vulpes/Canis familiaris) & 1 & 0.8 \\
\hline Seal (Phoca sp.) & 1 & 0.3 \\
\hline Tuna (Thunnus thynnus) & 27 & 49 \\
\hline Tuna? (Thunnus thynnus) & 9 & 12 \\
\hline Cod (Gadus morhua) & 1 & 0.5 \\
\hline Cod? (Gadus morhua) & 1 & 1.5 \\
\hline Deer familiy (Cervidae) & 5 & 10.3 \\
\hline Deer familiy? (Cervidae) & 2 & 2.2 \\
\hline Fish (Pisces sp.) & 27 & 20.7 \\
\hline Unidentified & 176 & 112 \\
\hline Total & 251 & 209.9 \\
\hline Burnt bone & NISP & Weight \\
\hline Seal (possibly harp seal, Pagophilus groenlandica) & 3 & 4.2 \\
\hline Ro deer (Capreolus capreolus) & 2 & 2.4 \\
\hline Fox (Vulpes vulpes) & 1 & 0.3 \\
\hline Fox/dog (Vulpes vulpes/Canis familiaris) & 4 & 0.9 \\
\hline Seal (Phoca sp.) & 7 & 5,7 \\
\hline Small mammal (Parvamammalia) & 4 & 0.5 \\
\hline Small to intermediary mammal (Parva-mesomammalia) & 1 & 0.1 \\
\hline Intermediary mammal (Mammalia) & 63 & 8.5 \\
\hline Bird (Aves sp.) & 2 & 0.2 \\
\hline Bird? (Aves sp.) & 2 & 0.2 \\
\hline Fish (Pisces sp.) & 6 & 0.6 \\
\hline Small animal (Parva-animale) & 3 & 0.3 \\
\hline Animal (Animale) & 1 & 0.1 \\
\hline Unidentified & 283 & 28.1 \\
\hline Total & 379 & 47.9 \\
\hline
\end{tabular}

$?=$ uncertain

Jonsson, 2007, p. 243; Munkenberg, 2007, pp. 114-115, Table 1; Skjølsvold, 1977). Small terrestrial game like roe deer may have been hunted on the island where the site was situated, but hunting expeditions were presumably also undertaken on the mainland. In the interior areas of Eastern Norway, winter sites associated with specialized elk hunting and a pit-dwelling dated to the Middle Neolithic have been excavated (Boaz, 1997, p. 131; Mjærum, 2018). Conceivably, PWC groups exploited terrestrial and marine species in different seasons, thus pointing to a mobile subsistence and settlement pattern. This suggests that these groups dwelled and operated in the environment in ways similar to that described for Mesolithic foragers. The Mesolithic traditions in south-eastern Norway are characterized by a diverse mobility, which allowed a flexible utilization of resources. This adaption made such communities resilient despite environmental fluctuation and changes in living conditions over time (Breivik, Fossum, \& Solheim, 2016; Berg-Hansen, 2017; Solheim, Damlien, \& Fossum, 2020). The occurrence of tuna speaks in favor of summer activities. The lack of solid dwellings, a distinctive trait for PWC sites in coastal southern Norway and western Sweden, also supports the use of the site in the warmer season (Munkenberg, 2007, p. 41; Solberg, 2015, pp. 99-101).

Cyclical use of the landscape ensures optimal utilization of the resources, but mobility is also shown to be fundamental in the social organization of hunter-gatherer life (Conkey, 1980; Mauss, 2013[1950]; Whallon, 2006). Seasonal fisheries, particularly with regards to anadromous fish like salmon, or seasonally recurring events like herring spawnings, are important events that play a key role not only in subsistence but also in communal life and ritual practices (Swezey \& Heizer, 1977). Seasonality involving encounters and confrontations with nondomestic animals, in specific seasonal and circadian rhythms, also play a 
significant role in structuring multispecies relations (Birch, 2018b; Hill, 2017; Overton, 2018; Taylor, 2020). In such a perspective, the site can be envisaged, not just as a location where people seasonally gathered to catch and consummate, but as a node in a network of movement within the larger landscape (Conneller, 2005, pp. 47-49) entangling humans and animals in various ways. At Alveberget, human-fish encounters were shaped and mediated by the experiences and practices involved in in-shore and out-shore fishing. The interaction involved in toggling of seals and large tuna differed practically, but presumably also conceptually, from the angling of small species of fish (Stewart (1982[1977]). Arguably, such encounters endorsed an animist and relational understanding of the PWC world.

\section{Animist Ontologies and the Role of Human-Animal Relations in Foraging Persistency}

Within the Western Scandinavian PWC, large fish and sea mammals appear to have been particularly significant in cosmology and ritual practices. Special deposits of bones from whales, dolphins, and large fishes are interpreted as ritual acts marking the initiation of a midden. Examples of this are the midden at Ånneröd, which was founded upon a layer of red oker, and at Dafter parts of three white-beaked dolphins, which were buried in a pit under the midden (Jonsson, 2007, p. 244). Similar parallels were observed at Auve in the Oslofjord-area, where skeletal remains of porpoises were found under the cultural layer (Østmo, 1984, p. 48). At Sandhem, burnt bones were moved from the fireplaces and gathered in specific pits, and at Rörvik deposits of bones from dogs, humans, and tooth pendants suggest that the middens were used for more than just domestic waste (Jonsson, 2007, pp. 244-245). The cultural importance of large terrestrial
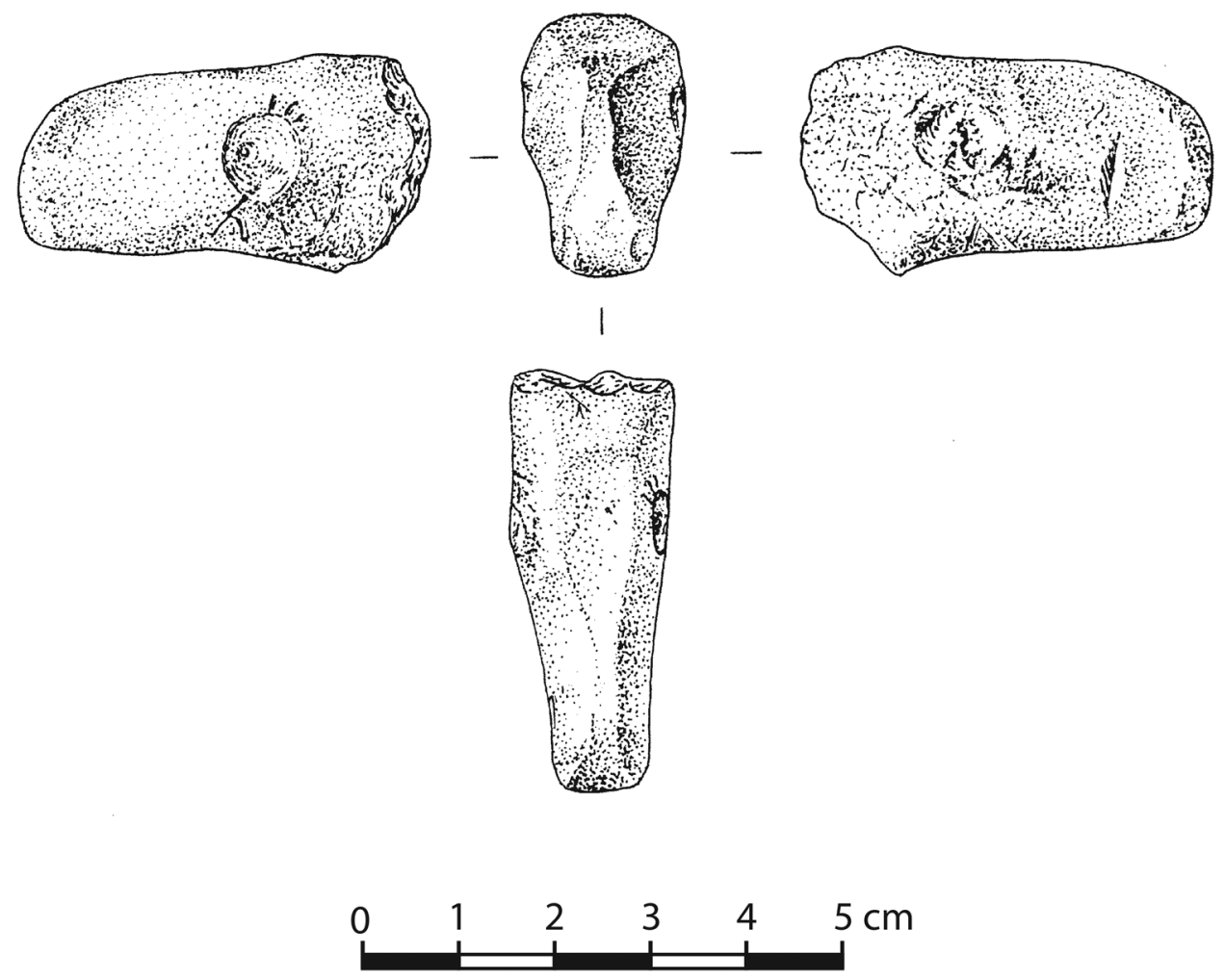

Figure 8: Figurine interpreted as a head of an elk, marked with eyes, eyebrows, and nostrils. Made from ceramics and retrieved at the Pitted Ware settlement site Solbakken 3, Ystehede, Halden County, Southeast Norway (after Østmo, 2007). Drawing: T. Strenger. Reprinted with kind permission from E. Østmo. 
mammals is also demonstrated by representations, such as the elk figurine, a head marked with eyes, eyebrows, and nostrils, which was recovered at Solbakken 3 (Østmo, 2007, Figure 8). Similar figurines have been found at Hæstad in Lillesand, Aust-Agder (Østmo, 2004). Elks and red deer appear at hunter-gatherer rock art sites dated to the Middle Neolithic at locations such as Nämforsen and Tumlehed (Gjerde, 2016; Paulsson, Isendahl, \& Markurth, 2019).

Naturalistic animal idols made of slate and other stone materials, representing animals like elk, bears, and whales, commonly occur on Middle Neolithic sites in Northern Scandinavia and eastern Sweden (Edenmo, Larsson, Nordqvist, \& Olsson, 1997; Fuglestvedt, 2018, pp. 394-396; Götherström, Stenbäck, \& Storå, 2002; Wyszomirska, 1984, pp. 106, 204-206). In other regions of Northern Scandinavia, where hunting and gathering remained the basis of the economy well into the chronological Neolithic, animal parts such as tooth pendants continued to be deposited in burials, and animal headdresses were used for ritual purposes (Lindström, 2020; Macāne, 2020; Osipowicz, Orłowska, Piličiauskienè, \& Piličiauskas, 2020). In Mesolithic archeology, such finds have been used to explore the cultural significance of animals, arguing that animal depictions and structured depositions reflect particular ways of perceiving animals (Conneller, 2004; Fuglestvedt, 2018; Gummesson, Hallgren, \& Kjellström, 2018; Mansrud, 2016; Schülke \& Hegdal, 2015; Taylor, 2020). It has further been proposed that a predominantly animist ontology characterized the Mesolithic hunter-gatherer communities in Northern Europe (c. 9300-4000 BCE) (Mansrud, 2016; Pedersen \& Petersen, 2017; Taylor, 2020). We suggest that this is also a relevant interpretive framework for addressing Middle Neolithic foraging communities.

An anthropological cross-cultural model can function as a useful heuristic device for exploring past ontologies (Fuglestvedt, 2018; Goldhahn, 2019, p. 67). Descolas' (2010, 2014) fourfold model of ontologies theorizes that human cultures universally relate to nonhumans by self-comparison and further maintains that human cultures have limited ways of perceiving and conceptualizing the relations between themselves and other species. He distinguishes four main relational modes: animism, totemism, analogism, and naturalism. In any given society, one ontological mode commonly dominates and unconsciously informs how people act in their practical and social everyday life. In small-scale foraging societies in the Northern hemisphere, animism commonly prevails (Descola, 2014, p. 361). Animism implies an understanding of the world in which the humans see themselves as a society separate from, but parallel to the societies of other living beings (Willerslev, 2007). In the animistic relational mode, nonhumans are personified and endowed with the same interiority and intentionality as humans, but humans and nonhumans are differentiated by their bodies, which determines how they see the world (Descola, 2010, p. 337; Viveiros de Castro, 2004). Such an approach recognizes the economic and dietary importance of animals in past hunter-gatherer life and does not imply a romantic view of prehistoric hunters as "kind" to animals (Pasarić \& Warren, 2019). Rather, it is the experience with predation, which underwrites the animist perception. Proteins are essential for sustaining human life; however, to retrieve them, animists must navigate in a social field alongside a variety of nonhuman actors:

[...] if you derive your main subsistence from hunting, it is not a bad bet to surmise that the prey you are pursuing has an interiority of its own, whether you call it cunning, a soul or a theory of mind, and that you should look at yourself as if you were that prey so as to organize your moves accordingly (i.e. deceiving the animal by not doing what it would expect you to do from the position where it may become aware of your presence). Systematized in discursive form, in myth and ritual statements, this perfectly normal inference about the dispositions of an animal, and the equally normal process of empathy with a higher form of animal life, constitutes the experiential basis of what I have called animism, i.e. the assumption that, under certain circumstances, non-humans of various kinds behave as if they had an intentionality analogous to the one humans believe they are endowed with (Descola, 2010, p. 335).

Among animist societies, personhood is often reserved for the larger species of prey, like elk, deer, and cassowary or for predatory mammals like the bear or the jaguar (e.g., Betts, Blair, \& Black, 2012; Hill, 2013; Ingold, 2000, p. 91; Kohn, 2013; Viveiros de Castro, 2004). Yet, marine species like salmon, halibut, sharks, whales and various sea-mammals are also perceived as persons in some coastal societies (Hill, 2017; Losey, 2010, pp. 19-20; Ween, 2012, p. 163). Deep-water fishing with a hook on a line or harpooning is occasionally represented in prehistoric hunter-gatherer rock art (Gjerde, 2016). This attests to the deep-seated cultural 
significance of this activity. While there is no direct evidence for special animal deposits, burials, or animal representations present at Alveberget, we find it justified to contextualize the site within such an overarching framework based on overall similarities in settlement patterns, subsistence base, material culture, and ritual practices evidenced at contemporary PWC sites.

Ontologies also influence how people express themselves visually (Descola, 2010, 2014, p. 273). For example, portable art emphasizing the natural shape and behavior of animals has been considered suggestive of animism, depicting animal "persons" dressed in their animal "clothing" (Ingold, 2000). In animist societies, human-human as well as human-animal relations are characterized by equality, negotiation, and sharing, and communicated through respectful treatment of animal remains (Ingold, 2000). Sometimes referred to as "the hunting cycle," these practices refer to hunter-gatherers' ongoing communication, confrontation, and ritual negotiation with the nonhuman community, perceived as similar-butdifferent from the society of humans, to secure the regeneration and return of the great animal herds or solitary animals (Fuglestvedt, 2018, pp. 396-398; Grøn, 2012). Interpreted in this framework, the naturalistic representations of elks from Nämforsen, the elk figurine from Solbakken, and the special treatment of animal body parts in PWC middens and burials can be interpreted as reminiscent of an animistic worldview.

\section{Alveberget in the Wider Regional Context of the PWC}

The activity phase at Alveberget concurs with a change in settlement location and intensified utilization of the coast and marine resources, presumably related to changes in sea temperatures, which created a rich habitat for marine organisms, including fish and their predators (Bennike et al., 2008; Jonsson, 1995, 2007; Nielsen et al., 2019). Several newly discovered coastal sites with similar findings (Mansrud, 2018; Nielsen \& Persson, 2020, pp. 10-12) as well as older assemblages (Hufthammer, 1997; Jonsson, 2007; Skjølsvold, 1977; Solberg, 2015) reveal a well-established tradition for complex aquatic resource utilization in the region of Southern Norway and Western Sweden. PWC groups in this region were targeting ungulates and large marine species like bluefin tuna, halibut, harp seal, harbour seal, porpoise, white-beaked dolphin, and possibly even orca (Bang-Andersen, 1981, p. 95; Hufthammer, 1997; Jonsson, 2007; Nielsen \& Persson, 2020; Skjølsvold, 1977). A mobile lifeway, guided by an animist ontology, endured and made the PWC groups resilient toward environmental, economic, and cultural changes. Why would these well-adapted foraging groups in a rich marine environment turn away from a traditional way of life to live as settled farmers?

Several scholars see the Middle Neolithic in Scandinavia as a period of agricultural recession where a full-time hunting and gathering life was resumed (Iversen, 2010, p. 5; Nielsen et al., 2019). Conversely, recent revisions of data from Western Norway argue that low-level cultivation and husbandry were gradually implemented by sedentary hunter-fisher-gatherers, commencing c. 3400 BCE or even earlier. These low-level agricultural practices were gradually expanded during the Middle Neolithic, before the final agricultural breakthrough came in the Late Neolithic c. 2350 BCE (Bergsvik et al., 2020). Some degree of supplementary small-scale cultivation in Agder cannot be completely ruled out. Charred grains of emmer and barley from the site Kvastad A2, $20 \mathrm{~km}$ north of Alveberget, were recently dated to 3500-2900 BCE (Ua52926 and Ua-52925, Reitan et al., 2018, p. 555). However, these findings were not uncovered on a shorebound PWC site, but located further inland, and unexpectedly recovered during excavation of a Mesolithic site. Grains from the same feature and sample were also dated to the Late Neolithic, and the feature is interpreted as representing two phases of cultivation or utilization of grains (Reitan et al., 2018, pp. 555-556).

The occurrence of lithic projectile points made from polished flint axes and the use of slate and rhyolite as raw material points to long-distance contacts with farming and foraging societies in southern Scandinavia and Western Norway. Neolithic axes also occur as stray finds along rivers in the interior of Agder (Nielsen \& Åkerstøm, 2016). The question of whether the stray finds in the interior and the foraging sites along the coast represent two parallel subsistence economies, belonging to different cultural groups, 
or whether low-level herding and/or cultivation was a subsidiary part of a broad-spectrum, largely huntergatherer-fisher economy, yet remains to be solved. In other regions, aDNA studies support a pluralist model of the Middle Neolithic period, suggesting that the BAC, FBC, and PWC cultures comprised interacting groups, which were genetically separate (Coutinho et al., 2020). Even though finds of charred cereals and domesticates indicate a multifaceted economy at some locales (Vanhanen et al., 2019), full-scale farming at PWC sites remains to be verified. Charred grains and cattle bones occurring at coastal PWC sites in Denmark (Iversen, 2010) might indicate contact with farming communities, rather than cultivation and pastoralism. A new analysis of pottery vessels deposited in bogs further shows that aquatic resources, associated with hunter-gatherer-fisher lifeways, were in use throughout the Early Neolithic and Middle Neolithic in Denmark (Robson et al., 2020).

Agricultural techniques are complex and require both knowledge and long-term experience in order to produce food successfully (Sørensen \& Karg, 2014, p. 109). In skerry coastal landscapes like Agder, with meager conditions for cultivation, there would be potentially great risks associated with basing the subsistence economy on farming (Zvelebil \& Dolukhanov, 1991, p. 248). In Norway, with limited areas of arable land, cold winters, and abundance of game and fish, fishing and hunting were never abandoned, but combined with cultivation and pasturing throughout historical times (Brøgger, 1925). Arguably, the role of agriculture, as opposed to a broad spectrum of resources, has been overstressed (Bevan et al., 2019), so perhaps it is time to rephrase Christopher Prescott's (1996) provocative question into why would there be a Neolithic in Norway? The traditional definition of the Neolithic, implying a complete replacement of the economic basis from foraging to farming, and the farmer-forager dichotomy maintained in the concept, is insufficient for exploring a region such as Southern Norway (Boyd, 2018; Grøn, 2012, p. 59; Zvelebil \& Dolukhanov, 1991). Recent findings indicate that hunter-gatherer engagement with the environment was biologically and economically complex in Northern Europe long before the transition to agriculture. Rather than being "ecologically adapted" hunter-gatherers, past and present have also actively intervened, transformed, cultivated, and manipulated the flora and fauna in the environment (Grøn, 2012; Groß et al., 2019; Warren, 2013).

In south-western Norway, a set of proxies reveal the human impact on the landscape through fire management, leading to decreased forest cover and formation of heathland commencing already in the late Mesolithic, c. 4700 BCE (Glørstad, 2009; Hjelle et al., 2018, p. 409; Prescott, 2020; Prøsch-Prøsch-Danielsen et al., 2020; Selsing, 2016). Archeological evidence and radiocarbon dates also indicate that current populations of trout in the Norwegian mountain lakes were established there by human intervention, presumably as early as the late Mesolithic (Heggenes, 2016; Mjærum \& Mansrud, 2020), and Fuglestvedt (2020) has recently suggested a scenario of short-lived small-scale domestication of reindeer in Alta. Such practices in hunter-gatherer resource utilization diminish the social and economic differences between farming and foraging and force us to rethink the relationship among hunting and gathering, the husbandry of genetically wild resources, and cultivation or herding of domesticated plants and animals (Grøn, 2012; Zvelebil \& Dolukhanov, 1991). Grøn (2012, p. 59) writes of the Siberian Evenks that they were "able to manipulate their system's resources to their own advantage to a degree that made them look unpleasantly Neolithic from an archaeologist's point of view." These engagements may have encompassed a wide range of relationships, from commensalism/mutualism to low-level management, and direct control over reproduction (Larsen, 2014, p. 6140). Hence, a fruitful way forward toward a broader understanding the economic strategies among Neolithic groups in South Norway would be to look for further evidence of PWC management of the resources in their environment.

\section{Conclusion}

The results presented here indicate that foraging remained central throughout the Neolithic period at the Alveberget site. The analysis of artifactual and faunal assemblages as well as lipid analysis from ceramics indicate a varied subsistence economy with terrestrial hunting and marine fishing, targeting cod, Atlantic 
bluefin tuna, and seals. Except for some bone fragments identified as dog, no evidence of domestic animals or cereal cultivation was retrieved, and the oldest unequivocal sign of cereal cultivation was dated to the Early Bronze Age. According to Prescott (2020, p. 14), the defining elements of a fully developed Neolithic economy comprises farming and cultivation, stockholding, and dwelling in dual-aisled longhouses. The late Neolithic material culture also involves a shift from lithic blade production to bifacial technology, flint daggers, and metal-age styles, as well as a more hierarchical organized society. Assuming that these changes were introduced rapidly as a "cultural package" by Bell Beaker groups migrating into southern Norway around 2400 BCE (Prescott, 1996, 2020), the Neolithic transition constitutes a complex structure of new practices, habits, techniques, and methods, which represents a complete socio-economic shift, involving the replacement of the building bricks of the society's traditional and socially transmitted knowledge (Berg-Hansen, 2017, 2018; Mauss, 1973[1935]). In addition to economic, social, and technological changes, settling down in long houses implies new ways of dwelling, and cultivation involved a different type of seasonal landscape utilization. Herding and stock-raising meant new ways of relating and living with domesticates (Oma, 2010, 2018). Arguably, the PWC groups in South Norway circumvented a fully developed Neolithic economy throughout most of the third millennium because too many elements were at odds with the traditional life ways, subsistence practices, interspecies relationships, and the prevailing animist worldview.

Acknowledgement: The authors wish to thank Jo-Simon Frøshaug Stokke, Monica Svendsen, Solveig S. Lyby, Gjermund Christensen, Morten Vetrhus, Eystein Østmoe, Isak Roaldkvam, Sondre Bruvik, Steinar Kristensen, Synnøve Viken and Per Persson for assisting in various ways during excavation and postexcavation work. We are also grateful for constructive comments and critiques provided by two anonymous reviewers.

Author contributions: Both authors have accepted responsibility for the entire content of this manuscript and approved its submission. Anja Mansrud prepared the main parts of the manuscript with contributions from Inger Marie Berg-Hansen. Berg-Hansen provided most of the illustrations and maps.

Conflict of interest: The authors state no conflict of interest.

Data availability statement: The datasets generated during and/or analyzed during the current study are available from the corresponding author on reasonable request.

\section{Abbreviations}

BCE before the current era

CE current era

MN middle Neolithic

PWC pitted ware culture

\section{References}

Bang-Andersen, S. (1981). En fangstboplass på Eigerøy - Boplassbruk og miljøtilpasning i sørvestnorsk yngre steinalder. AmSSkrifter, 6. Stavanger: AmS.

Bakka, E. (1973). Omkring problemet om kulturdualisme i Sør-Noreg. In P. Simonsen \& G. S. Munch (Eds.), Bonde - Veidemann. Bofast - Ikke Bofast i Nordisk Forhistorie. Tromsø Museums skrifter XIV (pp. 109-127). Tromsø: Tromsø Museum.

Becker, C. J. (1951). Den grubekeramiske kultur i Danmark. Aarbøger for Nordisk Oldkyndighed og Historie, 1950, $153-274$. 
Bennike, O., Rasmussen, P., \& Aaris-Sørensen, K. I. M. (2008). The harp seal (Phoca groenlandica Erxleben) in Denmark, southern Scandinavia, during the Holocene. Boreas, 37(2), 263-272.

Berg-Hansen, I. M. (2017). Den Sosiale Teknologien - Teknologi og tradisjon i Nord-Europa ved slutten av Istida, $10900-8500$ f.Kr. (PhD thesis). University of Oslo, Oslo.

Berg-Hansen, I. M. (2018). Continuity and change in Late Glacial and Postglacial social networks; knowledge transmission and blade production methods in Ahrensburgian and early Mesolithic north west Europe. In K. Knutsson, H. Knutsson, J. Apel, \& H. Glørstad (Eds.), The technology of early settlement in northern Europe - Transmission of knowledge and culture (Vol. 2, pp. 63-98). Sheffield: Equinox.

Bergsvik, K. A. (2012). The last hunter-fishers of western Norway. In H. Glørstad \& Chr. Prescott (Eds.), Becoming European: The transformation of third millennium northern and western Europe (pp. 100-114). Oxford: Oxbow Books.

Bergsvik, K., Hjelle, K., Halvorsen, L., Olsen, A., \& Zinsli, C. (2020). Low-level agriculture in Neolithic western Norway. In K. Gron, L. Sørensen, \& P. Rowley-Conwy (Eds.), Farmers at the frontier: A pan European perspective on Neolithisation (pp. 339-362). Oxford, Philadelphia: Oxbow Books. doi: 10.2307/j.ctv13gvh1g.20.

Betts, M. W., Blair, S. E. \& Black, D. W. (2012). Perspectivism, mortuary symbolism, and human-shark relationships on the maritime Peninsula. American Antiquity, 77(4), 621-645.

Bevan, A., Colledge, S., Fuller, D., Fyfe, R., Shennan, S., \& Stevens, C. (2017). Holocene fluctuations in human population demonstrate repeated links to food production and climate. Proceedings of the National Academy of Sciences, 114(49), E10524-E10531. doi: 10.1073/pnas.1709190114.

Binford, L. (2001). Constructing frames of reference: An analytical method for archaeological theory building using huntergatherer and environmental data sets. Berkeley: University of California Press

Birch, S. E. P. (2018a). Introduction. In S. E. P. Birch (Ed.), Multispecies archaeology (pp. 1-7). London/New York: Routledge.

Birch, S. E. P. (2018b). Seasonal mobility and multispecies interactions in the Mesolithic northeastern Adriatic. In S. E. P. Birch (Ed.), Multispecies archaeology (pp. 310-332). London/New York: Routledge

Boaz, J. (1997). Steinalderundersøkelsene på Rødsmoen. Varia, 41. Oslo: Universitetets Oldsaksamling.

Boyd, B. (2018). An archaeological telling of multispecies co-inhabitation: Comments on the origins of agriculture and domestication narrative in southwest Asia. In S. E. P. Birch (Ed.), Multispecies archaeology (pp. 251-269). London/New York: Routledge.

Breivik, H. M., Fossum, G., \& Solheim, S. (2016). Exploring human responses to climatic fluctuations and environmental diversity: Two stories from Mesolithic Norway. Quaternary International, 465, 258-275. doi: 10.1016/j.quaint.2016.12.019.

Brøgger, A. W. (1925). Det norske folk i Oldtiden. Institutt for sammenliknende kulturforskning, serie A, VI. Oslo: Institutt for Sammenliknende Kulturforskning.

Conkey, M. W. (1980). The identification of prehistoric hunter-gatherer aggregation sites: The case of Altamira. Current Anthropology, 21(5), 609-630.

Conneller, C. (2004). Becoming deer. Corporeal transformations at Star Carr. Archaeological Dialogues, 11(1), 37-56.

Conneller, C. (2005). Moving beyond sites: Mesolithic technology in the landscape. In N. Milner \& P. C. Woodman (Eds.), Mesolithic studies at the beginning of the twenty-first Century (pp. 42-55). Oxford: Oxbow Books.

Coutinho, A., Günther, T., Munters, A., Svensson, E., Götherström, A., Storå, J., ... Jakobsson, M. (2020). The Neolithic pitted ware culture foragers were culturally but not genetically influenced by the battle axe culture herders. American Journal of Physical Anthropology, 172, 638-649.

Craig, O. E., Forster, M., Andersen, S. H., Koch, E., Crombé, P., Milner, N. J., ... Heron, C. P. (2007). Molecular and isotopic demonstration of the processing of aquatic products in northern European prehistoric pottery. Archaeolmetry, 49, 135-152.

Dannevig, H. W., \& van der Eynden, J. (1986). Skagerrak-fiskerens historie. Oslo: Gyldendal.

Descola, P. (2010). Cognition, perception and worlding. Interdisciplinary Science Reviews, 35(3-4), 334-340.

Descola, P. (2014). Beyond nature and culture. Chicago: University of Chicago Press.

Edenmo, R., Larsson, M., Nordqvist, B., \& Olsson, E. (1997). Gropkeramikerna - fanns de? Materiell kultur och ideologisk förändring. In M. Larsson \& E. Olsson (Eds.), Regionalt och interregionalt: Stenåldersundersökningar i Syd-och Mellansverige (pp. 135-214). Stockholm: Riksantikvarieämbetet.

Fuglestvedt, I. (2018). Rock art and the wild mind: Visual imagery in Mesolithic northern Europe. London: Routledge.

Fuglestvedt, I. (2020). Scenes of human control of Reindeer in the Alta Rock Art. Current Swedish Archaeology, 28, $121-146$.

Gjerde, J. M. (2016). Marine ventures in the stone age rock art of Fennoscandia. In H. B. Bjerck, H. M. Breivik, S. E. Fretheim, E. L. Piana, A. M. Tivoli, B. Skar, \& A. F. J. Zangrano (Eds.), Marine ventures: Archaeological perspectives on human-sea relations (pp. 337-354). Sheffield: Equinox Publishing.

Glørstad, H. (2002). Neolittisk renessanse. Hypoarkeologiske tekster om neolitikum i Sør-Norge. Oslo: Unipub/Oslo Academic Press \& Institutt for Arkeologi, Konservering og Historie, Universitetet i Oslo.

Glørstad, H. (2009). The northern Province? The Neolithisation of southern Norway. In H. Glørstad \& Chr. Prescott (Eds.), Neolithisation as if history mattered. Processes of neolithisation in north-western Europe (pp. 135-168). Lindome: Bricoleur.

Glørstad, H. (2010). The structure and history of the Late Mesolithic societies in the Oslo fjord area 6300-3800 BC. Gothenburg: Bricoleur Press. 
Glørstad, H., \& Solheim, S. (2015). The Hamremoen enclosure in southeastern Norway. An exotic glimpse into the process of Neolithization. In K. Brink, S. Hydén, K. Jennbert, L. Larsson, \& D. Olausson (Eds.), Neolithic diversities. Perspectives from a conference in Lund, Sweden. Acta Archaeologica Lundensia Series in $8^{\circ}$ (65) (pp. 139-152). Lund: Lund University.

Glørstad, H., Solheim, S., \& Persson, P. (2020). Culture and context of the Scandinavian Neolithic. In K. J. Gron, L. Sørensen, \& P. Rowley-Conwy (Eds.), Farmers at the frontier: A pan European perspective on Neolithisation (pp. 363-380). 0xford, Philadelphia: Oxbow Books. doi: 10.2307/j.ctv13gvh1g.21.

Goldhahn, J. (2019). On unfolding present and past (rock art) worldings. Time and Mind, 12(2), 63-77.

Groß, D., Piezonka, H., Corradini, E., Schmölcke, U., Zanon, M., Dörfler, W., ... Wilken, D. (2019). Adaptations and transformations of hunter-gatherers in forest environments: New archaeological and anthropological insights. The Holocene, 29(10), 1531-1544.

Grøn, 0. (2012). Our grandfather sent the elk-some problems for hunter-gatherer predictive modelling. Quartär, 59(2012), 175-188.

Gummesson, S., Hallgren, F., \& Kjellström, A. (2018). Keep your head high: Skulls on stakes and cranial trauma in Mesolithic Sweden. Antiquity, 92(361), 74-90.

Götherström, A., Stenbäck, N., \& Storå, J. (2002). The Jettböle middle Neolithic site on the Åland Islands - Human remains, ancient DNA and pottery. European Journal of Archaeology, 5(1), 42-69.

Hallgren, F. (2008). Identitet i praktik: Lokala, regionala och överregionala sociala sammanhang inom nordlig trattbägarkultur. (PhD thesis). Kust till kust-böcker 17. Departement of Archaeology and Ancient History, Uppsala University, Uppsala.

Heggenes, J. (2016). Fisken i fjellet i fortid og nåtid. Hva k an DNA-analyser fortelle? Fjellfiske i fortiden. Årtusener med svømmende rikdom (pp. 81-91). Oslo: Portal.

Henriksen, G. (2010). Hunters in the barrens: The Naskapi on the edge of the white man's world. New York/Oxford: Berghahn Books.

Hernek, R., Jonsson, L., \& Streiffert, J. (2004). Boplatser och kökkenmöddingar från yngre neolitikum. Arkeologisk utredning och förundersökning inför rätning av Bohusbanan. Bohuslän, Skee socken. Hedängen 3: 6, 3: 10 och Sandhem 3: 6, RAÄ 1617 och 1618. Arkeologisk rapport. Riksantikvarieämbetet UV Väst.

Hill, E. (2013). Archaeology and animal persons: Toward a prehistory of human-animal relations. Environment and Society, 4(1), 117-136. doi: 10.3167/ares.2013.040108.

Hill, E. (2017). The archaeology and ethnohistory of walrus ritual around bering strait. Études Inuit Studies, 41(1-2), 73-99.

Hinsch, E. (1955). Traktbegerkultur-Megalitkultur. En studie av Øst-Norges eldste, neolittiske gruppe. Universitetes Oldsaksamlings Årbok, 1951-1953, 1-237.

Hinsch, E. (1956). Yngre steinalders stridsøkskulturer i Norge. Årbok, 1954, Historisk-antikvarisk rekke. Bergen: Universitetet i Bergen.

Hjelle, K. L., Halvorsen, L. S., Prøsch-Danielsen, L., Sugita, S., Paus, A., Kaland, P. E., ... Midtbø, I. (2018). Long-term changes in regional vegetation cover along the west coast of southern Norway: The importance of human impact. Journal of Vegetation Science, 29(3), 404-415.

Hjelle, K. L., Hufthammer, A. K., \& Bergsvik, K. A. (2006). Hesitant hunters: A review of the introduction of agriculture in western Norway. Environmental Archaeology, 11(2), 147-170.

Hufthammer, A. K. (1992). De osteologiske undersøkelsene fra Kotedalen. In K. L. Hjelle, A. K. Hufthammer, P. E. Kaland, A. B. Olsen, \& E. C. Soltvedt (Eds.), Kotedalen - En boplass gjennom 5000 år. Bind 2. Naturvitenskapelige undersøkelser (pp. 9-64). Bergen: Universitetet i Bergen.

Hufthammer, A. K. (1997). The vertebrate faunal remains from Auve-a palaeoecological investigation. Auve. Bind II. Tekniske og naturvitenskapelige undersøkelser. Norske Oldfunn XVII. Institutt for arkeologi, kunsthistorie og numismatikk. Oslo: Universitets Oldsaksamling.

Hufthammer, A. K. (2006). The vertebrate fauna of eastern Norway - From the ice age to the middle ages. In H. Glørstad, D. Skre, \& B. Skar (Eds.), Historien i forhistorien. Festskrift til Einar Østmo på 60-årsdagen (pp. 91-202). 0slo: Kulturhistorisk Museum, Universitetet i Oslo.

Indrelid, S. (1994). Fangstfolk og bønder i fjellet: Bidrag til Hardangerviddas førhistorie 8500-2500 år før nåtid. Universitetets Oldsaksamlings Skrifter. Ny rekke, nr. 17. Oslo: Universitetets Oldsaksamling.

Ingold, T. (2000). Chapter seven. Totemism, animism and the depiction of animals. The perception of the environment: Essays on livelihood, dwelling and skill (pp. 111-131). London: Routledge.

Isaksson, S. (2019). Analys av organiska lämningar i keramik från Alveberget. Uppdragsrapport nr. 335. Stockholm: Arkeologiska Forskningslaboratoriet, Stockholms Universitet.

Iversen, R. (2010). In a world of worlds. The Pitted Ware complex in a large scale perspective. Acta Archaeologica, 81, 5-43.

Jonsson, L. (1995). Vertebrate fauna during the Mesolithic on the Swedish west coast. In A. Fischer (Ed.), Man and sea in the Mesolithic - Coastal settlement above and below sea level. Oxbow Monograph 53 (pp. 147-160). Oxford: Oxbow.

Jonsson, L. (2007). Djurbenen från Sandhem. In M. Lönn, \& P. Claesson (Eds.), Vistelser vid vatten. Gropkeramiska platser och kokgropar från brånsålder och järnålder. Riksantikvarieämbetet arkeologiska underökningar skrifter, 69 (pp. 233-251). Ödeshög: Riksantikvarieämbetet/Bohusläns Museum.

Kelly, R. L. (2013 [1995]). The lifeways of hunter-gatherers. The foraging spectrum. Cambridge: Cambridge University Press. 
Kohn, E. (2013). How forests think: Toward an anthropology beyond the human. Berkely/Los Angeles: University of California Press.

Larsen, G. (2014). Current perspectives and the future of domestication studies. Proceedings of the National Academy of Sciences, 111(17), 6139-6146.

Lindström, T. (2020). Retrieving, curating and depositing skulls at pitted ware culture sites. Current Swedish Archaeology, 28, 147-179.

Losey, R. (2010). Animism as a means of exploring archaeological fishing structures on Willapa Bay, Washington, USA. Cambridge Archaeological Journal, 20(1), 17-32.

Lundholm, J., \& Ekman, E. (2020). Reporting measurements of isotope and mass fractions of C and N. Department of Forest Ecology and Management, Swedish University of Agricultural sciences.

Macāne, A. (2020). Petrified animals: Fossil beads from a Neolithic hunter-gatherer double burial at Zvejnieki in Latvia. Antiquity, 94(376), 916-931.

Macphail, R. (2019, February). Alveberget, Arendal kommune, Aust-Agder, Norway: Soil micromorphology Report for Cultural History Museum. University of Oslo.

Mansrud, A. (2016). Smitt og smuler. Brente bein, avfallshåndtering og rituell praksis på mellommesolittiske boplasser $\mathrm{i}$ Oslofjordsområdet (8300-6300 f.Kr.). In Situ Archaeologica, 12, 7-29.

Mansrud, A. (2018). Undersøkelse av lokaliteter fra steinalder i forbindelse med feltkurs 2017/2018. Brukjerr 3 og Brukjerr 8 , Molland, 82/1, Grimstad, Aust-Agder. Rapport Arkeologisk utgravning. Oslo: Kulturhistorisk Museum, Universitetet i Oslo.

Mansrud, A., Stokke, J.-S. F., Viken, S., \& Berg-Hansen, I. M. (in press). Boplass fra yngre steinalder med kulturlag, organisk materiale og keramikk. Bjelland 218/4, Arendal, Agder. Arkeologisk rapport. Oslo: Kulturhistorisk Museum, Universitetet i Oslo.

Mauss, M. (1973 [1935]). Techniques of the body. Economy and Society, 2(1), 70-88.

Mauss, M. (2013 [1950]). Seasonal variations of the Eskimo: A study in social morphology. London/New York: Routledge.

Mischka, D., Furholt, M., Hinz, M., Noble, G., \& Olausson, D. (2014). Foreword. In M. Furholt, M. Hinz, D. Mischka, G. Noble, \& D. Olausson (Eds.), Landscapes, histories and societies in the northern European Neolithic. Frühe Monumentalität und soziale Differenzierung, 4 (pp. 11-16). Kiel: Verlag Dr. Rudolf Habelt.

Mikkelsen, E. (1989). Fra jeger til bonde. Utviklingen av jordbrukssamfunn i Telemark i steinalder og bronsealder. Universitetets Oldsaksamlings Skrifter, Ny rekke, 11. Oslo: Universitetets Oldsaksamling.

Mjærum, A. (2018). Hunting elk at the foot of the mountains. Remains from 8000 years of foraging at the edge of the Hardangervidda plateau in southern Norway. In P. Persson, F. Riede, B. Skar, H. M. Breivik, \& L. Jonsson (Eds.), The early settlement of northern Europe. Climate, human ecology, and subsistence (pp. 167-196). Sheffield: Equinox Publishing.

Mjærum, A., \& Mansrud, A. (2020). Resource management in Late Mesolithic eastern Norway? Fishing in the coastal, interior and mountain areas and its socio-economic implications. In A. Schülke (Ed.), Coastal landscapes of the Mesolithic: Human engagement with the coast from the Atlantic to the Baltic Sea (pp. 246-299). London/New York: Routledge.

Munkenberg, B. A. (2007). De gropkeramiska boplatserns miljö. In M. Lönn \& P. Claesson (Eds.), Vistelser vid vatten. Gropkeramiska platser och kokgropar från brånsålder och järnålder. Riksantikvarieämbetet arkeologiska underökningar skrifter, 69 (pp. 105-148). Ödeshög: Riksantikvarieämbetet/Bohusläns Museum.

Nielsen, S. V., \& Åkerstrøm, J. (2016). Yngre steinalders flint-og steinøkser fra Aust-Agder fylke. Aust-Agder-Arv, 3-15.

Nielsen, S. V., Persson, P., \& Solheim, S. (2019). De-Neolithisation in southern Norway inferred from statistical modelling of radiocarbon dates. Journal of Anthropological Archaeology, 53, 82-91. doi: 10.1016/j.jaa.2018.11.004.

Nielsen, S. V., \& Persson, P. (2020). The Jortveit farm wetland: A Neolithic fishing site on the Skagerrak coast, Norway. Journal of Wetland Archaeology, 19, 1-26. doi: 10.1080/14732971.2020.1776495.

Nielsen, A. B., \& Rundgren, M. (2019a). Rapportering av dateringsresultat, Batch 1681, Alveberget, Arendal, Agder. Laboratoriet för C14-datering, Lunds Universitet.

Nielsen, A. B., \& Rundgren, M. (2019b). Rapportering av dateringsresultat fra analyse av korn, Batch 1795, Alveberget, Arendal, Agder. Laboratoriet för C14-datering, Lunds Universitet.

Nielsen, A. B., \& Rundgren, M. (2020). Rapportering av dateringsresultat av matskorper, Batch 1884, Alveberget, Arendal, Agder. Laboratoriet för C14-datering, Lunds Universitet.

Nærøy, A. J. (1993). Chronological and technological changes in western Norway 6000-3800 BP. Acta Archaeologica, 63, 77-95.

O'Connor, T. (2018). Animal and the Neolithic. Cui bono? In S. E. P. Birch (Ed.), Multispecies archaeology (pp. 201-213). London/New York: Routledge.

Olsen, A. B. (1992). Kotedalen - En boplass gjennom 5000 år. Bind I. Fangstbosetning og tidlig jordbruk i vestnorsk steinalder: Nye funn og nye perspektiver. Bergen: Historisk Museum, Universitetet i Bergen.

Olsen, A. B. (2013). Jordbrukskulturens pionertid på Vestlandet. Hus, åker og territorialitet. In S. Diinhoff, M. Ramstad, \& T. Slinning (Eds.), UBAS nordisk 7. Jordbruksbosetningens utvikling på Vestlandet (pp. 129-148). Bergen: University of Bergen.

Oma, K. A. (2010). Between trust and domination: Social contracts between humans and animals. World Archaeology, 42(2), 175-187. 
Oma, K. A. (2018). The sheep people: The ontology of making lives, building homes and forging herds in early bronze age Norway. Sheffield: Equinox Publishing Limited.

Oma, K. A., \& Goldhahn, J. (2020). Introduction: Human-animal relationships from a long-term perspective. Current Swedish Archaeology, 28, 11.

Osipowicz, G., Orłowska, J., Piličiauskienė, G., \& Piličiauskas, G. (2020). Frontlets from the south-east coast of the Baltic Sea? Seal craniums from Šventoji: A unique clue to understanding the symbolic culture of European middle Holocene huntergatherers. Journal of Archaeological Science: Reports, 34, 102638. doi: 10.1016/j.jasrep.2020.102638.

Östman, S. Hristova, I., Eriksson, S., Hristov, K., \& Wallin, J. E. (2019). Environmental archaeological analysis of samples from the Neolithic site of Alveberget, Arendal kommune, Aust-Agder Fylke. ID219491. Rapport nr. 2019-033. Umeå: Miljöarkeologiska laboratoriet, Umeå Universitet.

Østmo, E. (1984). Auve. Noen inntrykk fra en mellomneolittisk kystboplass i Vestfold. Viking, XLVII, 42-65.

Østmo, E. (1988). Etableringen av jordbrukskultur i Østfold $i$ steinalderen. Universitetets Oldsaksamlings Skrifter, ny rekke, 10. Oslo: Universitetets Oldsaksamling.

Østmo, E. (2004). En fangstboplass fra yngre steinalder på Solbakken i Idd, og en uventet elgskulptur. Et notat. Viking, LXVII, 35-48.

Østmo, E. (2007). Solbakken 3, Ystehede, Halden. Boplass med gropkeramisk materiale. In I. Ystgaard \& T. Heibreen (Eds.), Arkeologiske undersøkelser 2001-2002. Varia, 62 (pp. 77-88). Oslo: Kulturhistorisk Museum, Universitetet i Oslo

Østmo, E. (2008). Auve. En fangstboplass fra yngre steinalder på Vesterøya Sandefjord. Bind I. Den arkeologiske del. Norske Oldfunn XXVIII. Oslo: Kulturhistorisk Museum, Universitetet i Oslo.

Østmo, E. (2010). The cord stamp in Neolithic Scandinavia. Cultures of the Scandinavian Neolithic. Acta Archaeological, 81 (1), 44-71. doi: 10.1111/j.1600-0390.2010.00263.x.

Overton, N. J. (2018). The rhythm of life. Exploring the role of daily and seasonal rhythms in the development of humannonhuman relationships in the British Early Mesolithic. In S. E. P. Birch (Ed.), Multispecies archaeology (pp. 295-309). London: Routledge.

Overton, N. J., \& Hamilakis, Y. (2013). A manifesto for a social zooarchaeology. Swans and other beings in the Mesolithic. Archaeological dialogues, 20(2), 111-136.

Pasarić, M., \& Warren, G. M. (2019). Interactions of care and control: Human-animal relationships in hunter-gatherer communities in near-contemporary eastern Siberia and the Mesolithic of northwest Europe. Cambridge Archaeological Journal, 29(3), 465-478. doi: 10.1017/S095977431900012X.

Paulsson, B. S., Isendahl, C., \& Markurth, F. F. (2019). Elk heads at sea: Maritime hunters and long-distance boat journeys in late stone age Fennoscandia. Oxford Journal of Archaeology, 38(4), 398-419. doi: 10.1111/ojoa.12180.

Pedersen, K. B., \& Petersen E. B. (2017). Bringing home the elk: Preboreal elk deposits from southern Scandinavia. In M. Sørensen \& K. B. Pedersen (Eds.), Problems in Palaeolithic and Mesolithic research, arkeologiske studier (Vol. 12, pp. 237-256). København: Copenhagen University.

Persson, P. (1998). Neolitikums början. Undersøkningar kring jordbrukets introduksjon i Nordeuropa. (PhD thesis). Arkeologiska institutionen, Göteborgs Universitet, Göteborg.

Prata, S., \& Sjöling, E. (2019). Osteologisk analys. Brända och obrända djurben från en neolitisk kustlokal, Alveberget 8 , Tromøy, Arendal kommune, Aust-Agder. Prosjektnummer 430396. SAU rapport 2019:8. Uppsala: Societas Archaeologica Upsaliensis.

Possnert, G., \& Balkefors, J. (2018). Resultat av $14 C$ datering av träkol från Alveberget lok. 8, Arendal, Tromøya, Aust-Agder, Norway. Ångströmlaboratoriet, Uppsala Universitet.

Prescott, C. (1996). Was there really a Neolithic in Norway? Antiquity, 70(267), 77-87.

Prescott, C. (2020). Interpreting complex diachronic 'Neolithic'-period data in Norway. In K. Gron, L. Sørensen, \& P. RowleyConwy (Eds.), Farmers at the frontier: A pan European perspective on Neolithisation (pp. 381-400). Oxford, Philadelphia: Oxbow Books. doi: 10.2307/j.ctv13gvh1g.22.

Prescott, Chr., \& Glørstad, H. (2012). Introduction. In Chr. Prescott \& H. Glørstad (Eds.), Becoming European: The transformation of third millennium northern and western Europe (pp. 1-11). Oxford: Oxbow Books.

Prøsch-Danielsen, L., Prescott, C., \& Fredh, E. D. (2020). Land cover and exploitation of upland resources on the Høg-Jæren Plateau, southwestern Norway, over the last 6500 years. Journal of Archaeological Science: Reports, 32, 102443.

Reitan, G., Sundström, L., \& Stokke, J.-S. F. (2018). Grains of truth. Neolithic farming on Mesolithic sites. New Insight into early agriculture in southeast Norway. In G. Reitan \& L. Sundtröm (Eds.), The stone age coastal settlement in Aust-Agder, southeast Norway archeological excavations along the new E18 Tvedestrand-Arendal (pp. 547-565). Oslo: Cappelen Damm Akademisk.

Reimer, P., Austin, W., Bard, E., Bayliss, A., Blackwell, P., Bronk Ramsey, C., ... Talamo, S. (2020). The IntCal20 northern hemisphere radiocarbon age calibration curve (0-55 cal kBP). Radiocarbon, 62(4), 725-757.

Romundset, A. (2018). Postglacial shoreline displacement in the Tvedestrand-Arendal area. In G. Reitan \& L. Sundtröm (Eds.), The stone age coastal settlement in Aust-Agder, southeast Norway archeological excavations along the new E18 Tvedestrand-Arendal (pp. 463-478). Oslo: Cappelen Damm Akademisk.

Schülke, A., \& Hegdal, H. (2015). Et unikt mesolittisk anheng fra Brunstad i Vestfold. Viking, 78, 27-46. 
Selsing, L. (2016). Intentional fire management in the Holocene with emphasis on hunter-gatherers in the Mesolithic in South Norway (AmS-skrifter, 25). Stavanger: Arkeologisk museum i Stavanger. http://hdl.handle.net/11250/2433170.

Skjølsvold, A. (1977). Slettabøboplassen. Et bidrag til diskusjonen om forholdet mellom fangst-og bondesamfunn i yngre steinalder og bronsealder (AmS-Skrifter 2). Stavanger: Arkeologisk Museum i Stavanger.

Solberg, A. (2015). Steinalderliv på Helganes. Arkeologiske undersøkelser av en mellomneolittisk boplass i skjæringspunktet mellom nord og sør. Helganesprosjektet 2011-2013, Karmøy kommune, Rogaland. AmS-Varia 56. Stavanger: Arkeologisk Museum, Universitetet i Stavanger.

Solheim, S. (2012). Lokal praksis og fremmed opphav: Arbeidsdeling, sosiale relasjoner og differensiering i østnorsk tidligneolitikum. (PhD thesis). Humanistisk Fakultet, Universitetet i Oslo, Oslo.

Solheim, S., Damlien, H., \& Fossum, G. (2020). Technological transitions and human-environment interactions in Mesolithic southeastern Norway, 11 500-6000 cal. BP. Quaternary Science Reviews, 246, 106501. doi: 10.1016/ j.quascirev.2020.106501.

Sørensen, L., \& Karg, S. (2014). The expansion of agrarian societies towards the north-new evidence for agriculture during the Mesolithic/Neolithic transition in Southern Scandinavia. Journal of Archaeological Science, 51, 98-114. doi: 10.1016/ j.jas.2012.08.042.

Stewart, H. (1982 [1977]). Indian fishing: Early methods on the northwest coast. Vancouver: Douglas \& McIntyre.

Swezey, S. L., \& Heizer, R. F. (1977). Ritual management of salmonid fish resources in California. The Journal of California Anthropology, 4(1), 7-29.

Taylor, B. (2020). Plants as persons: Perceptions of the natural world in the north European Mesolithic. Time and Mind, $13,1-24$.

Van de Noort, R. (2011). North Sea archaeologies: A maritime biography, 10,000 BC-AD 1500. Oxford: Oxford University Press.

Vanhanen, S., Gustafsson, S., Ranheden, H., Björck, N., Kemell, M., \& Heyd, V. (2019). Maritime hunter-gatherers adopt cultivation at the farming extreme of northern Europe 5000 years ago. Scientific Reports, 9(1), 1-11. doi: 10.1038/s41598019-41293-z.

Viveiros de Castro, E. (2004). Exchanging perspectives: The transformation of objects into subjects in Amerindian ontologies. Common Knowledge, 10(3), 463-484.

Wammer, E. U., Mansrud, A., Nymoen, P., \& Kvalø, F. (2019). Mistet på sjøen? En nyoppdaget fiskekrok fra steinalderen i Søgne, Vest-Agder. Primitive Tider, 21, 25-43. doi: 10.5617/pt.7534.

Warren, G. (2013). The adoption of agriculture in Ireland: Perceptions of key research challenges. Journal of Archaeological Method and Theory, 20(4), 525-551.

Ween, G. (2012). Resisting the imminent death of wild Salmon: Local knowledge of Tana fishermen in Arctic Norway. In C. Carothers, K. R. Criddle, C. P. Chambers, P. J. Cullenberg, J. A. Fall, A. H. Himes-Cornell, ... E. S. Springer (Eds.), Fishing people of the north: Cultures, economies, and management responding to change (pp. 153-170). Fairbanks: Alaska Sea Grant, University of Alaska Fairbanks.

Whallon, R. (2006). Social networks and information: Non-“utilitarian" mobility among hunter-gatherers. Journal of Anthropological Archaeology, 25, 259-270.

Willerslev, R. (2007). Soul hunters. Hunting, Animism, and Personhood among the Siberian Yukaghirs Berkely/Los Angeles: University of California Press.

Wyszomirska, B. (1984). Figurplastik och gravskick hos Nord-och Nordösteuropas neolitiska fångstkulturer. Lund: Acta Archaeologica Lundensia. Series in $4^{\circ}$, No 18: Lund.

Zvelebil, M., \& Dolukhanov, P. (1991). The transition to farming in eastern and northern Europe. Journal of World Prehistory, 5(3), 233-278. 